Article

\title{
Energy Portfolio of the Eastern Poland Macroregion in the European Union
}

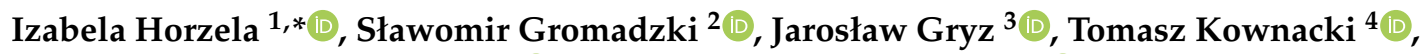 \\ Aneta Nowakowska-Krystman ${ }^{1}\left(\mathbb{D}\right.$, Marzena Piotrowska-Trybull ${ }^{1}\left(\mathbb{D}\right.$ and Radosław Wisniewski ${ }^{4}$ (1) \\ 1 Management and Command Faculty, Institute of Management, War Studies University, \\ 00-910 Warsaw, Poland; a.krystman@akademia.mil.pl (A.N.-K.); m.trybull@akademia.mil.pl (M.P.-T.) \\ 2 The Faculty of Technical and Social Sciences, Ignacy Moscicki's University of Applied Sciences in Ciechanów, \\ 06-400 Ciechanów, Poland; slawomir.gromadzki@puzim.edu.pl \\ 3 National Security Faculty, War Studies University, 00-910 Warsaw, Poland; j.gryz@akademia.mil.pl \\ 4 Faculty of Political Science and International Studies, University of Economics and Human Sciences in \\ Warsaw, 01-043 Warsaw, Poland; t.kownacki@vizja.pl (T.K.); r.wisniewski@vizja.pl (R.W.) \\ * Correspondence: i.horzela@akademia.mil.pl
}

check for

updates

Citation: Horzela, I.; Gromadzki, S.; Gryz, J.; Kownacki, T.;

Nowakowska-Krystman, A.; Piotrowska-Trybull, M.; Wisniewski, R. Energy Portfolio of the Eastern Poland Macroregion in the European Union. Energies 2021, 14, 8426.

https://doi.org/10.3390/en14248426

Academic Editor: Ben McLellan

Received: 17 November 2021

Accepted: 8 December 2021

Published: 14 December 2021

Publisher's Note: MDPI stays neutral with regard to jurisdictional claims in published maps and institutional affiliations.

Copyright: (C) 2021 by the authors. Licensee MDPI, Basel, Switzerland. This article is an open access article distributed under the terms and conditions of the Creative Commons Attribution (CC BY) license (https:/ / creativecommons.org/licenses/by/ $4.0 /)$.

\begin{abstract}
The European Union's New Green Deal generates changes in the socio-economic development of regions. An element of this change is the transformation of the regional profiles of the energy portfolio towards more pro-ecological ones. The aim of this article is to identify the conditions and reasons for the transformation of the energy portfolio of the Eastern Poland macroregion, and to define the directions of the energy portfolio evolution caused by the need to implement the goals of the European Green Deal by 2030, in order to consequently develop the forecast energy portfolio for the Eastern Poland macroregion. It has been assumed that the energy transformation of the Eastern Poland macroregion will be implemented through gradual transformation of the energy portfolio towards dispersed sources of local and civic energy. The research is based on both qualitative and quantitative approaches. The qualitative research was carried out on the basis of the diagnostic survey method with the use of the proprietary questionnaire as well as with the analysis of the content of strategic documents of the voivodships included in the Eastern Poland macroregion. The basis for the preparation of research questions was the extended PEST method which stands for: political, economic, socio-cultural, technological. Research efforts were focused on developing an energy portfolio for the region using the assumptions of the Boston consulting group matrix (a strategic planning tool). The originality of the conducted research consists in the adaptation of the BCG matrix to the development of the forecast energy portfolio and the preparation of a proposal for the aggregated energy portfolio of the Eastern Poland macroregion. The obtained results indicate that the macroregion's energy portfolio is diversified, though with the key significance of conventional sources. It is predicted that by 2030, the following sources will change their positions within the portfolio for the Eastern Poland macroregion: solar energy, wind energy and bioenergy. However, it will retain the character of a "youth wallet".
\end{abstract}

Keywords: green energy; macro region Eastern Poland; energy portfolio

\section{Introduction}

The New Green Deal aiming to achieve climate neutrality by 2050 requires a costeffective, fair and sustainable socio-economic transformation of all the EU's geographical regions [1]. This will take place over four financial terms, the first of which is between 2021 and 2027 [2]. This transformation is vital to the future of the organisation, particularly in the area of energy transition and moving away from the use of fossil fuels [3] (pp. 2-24). It shapes its impact and decides on the forms and levels of national, regional and local implementation of Union policy, determining its success or failure [4]. The above-mentioned levels are interrelated, mutually coupled, and their interaction defines and characterises the 
conditions necessary for the introduction of changes in four dimensions: political, social, economic, and technological. They prescribe the selection and modification of existing ways of acquiring and exploiting energy.

The first perspective concerns political action, including legal solutions, which should be understood through the prism of the European Union's multi-level political system, at the level of its institutions [5]. Given the standpoints of Member State representatives and the decision-making mechanisms, particularly national ones, the issue of energy transition choice remains open [6]. The decisive factor is the attitude of political groups to the proposed changes [7]. Furthermore, the belief that green changes need to be strengthened or that the status quo for the existing energy portfolio needs to be maintained [8]. This is a driver of uncertainty, thus generating research directions into changes in party political agendas and conscious political leadership regionally as well as in individual states [9].

The second cognitive perspective influencing the choice of energy portfolio is social preferences. In the case of Poland, these are conditioned by the strong traditions of its energy sector, which are based on conventional energy sources, particularly coal [10] (pp. 171-182). In this perspective, the issue concerns the determinants of change in the education and labour markets [11] and, furthermore, the transformation of the structure of energy production from centralised to decentralised. Over time, both these processes must undergo far-reaching transformations correlated with changes in the consciousness, and moreover, in the identities of the regional and local communities.

The third cognitive perspective is generated by economic politics related to the gains and possible losses for a given region resulting from the changes introduced by the Green Deal of the European Union. This is about the economic activity of the country, the European Union, and its influence on the world. The economic sphere is pivotal in terms of supporting the energy transition [12]. It provides a range of arguments for central and regional authorities to justify changes to existing national and regional policies, as well as enabling considerations for the welfare of their populations to be advanced [13]. Environmental considerations are also included in this area, affecting decisions on the location of energy sources, energy distribution, and the removal of greenhouse gas emissions [14]. This perspective directly appeals to the consciousness of each citizen. What is decisive in this area are the approaches to economic development and their interpretations that allow the results of the changes brought about by the European Union's Green Deal to be communicated clearly and coherently to society [15]. The decisive factor is the forms of communication appropriate for the intended goals of EU institutions and the ways they define how countries and their regions understand the changes taking place in their respective energy portfolios.

The fourth perspective is defined by the technical capacity to acquire, transmit, and ultimately, use energy [16]. Development is characterised by: the state of the energy infrastructure, technological advances, including software to optimise the management of energy consumption and storage, research in the renewable energy sector, and the formula for reducing pollution resulting from energy use [17] (pp. 28-37).

These perspectives define the shape of the energy portfolio of both individual European Union countries and its regions. A reference for the considerations presented here is the Eastern Poland macroregion, which includes five provinces: Lubelskie, Podlaskie, Podkarpackie, Świętokrzyskie and Warmińsko-Mazurskie. It has been defined in the last two EU financial periods of 2007-2013 and 2014-2020. They have delivered expenditure on territorial cohesion and accessibility, the development of innovative entrepreneurship, and on investments in public transport, roads and railways that are important for the macroregion. In the next financial perspective for 2021-2027, expenditure is realised from European Funds for the Eastern Poland Programme, which has been extended to include the Mazowieckie Province with the exception of the Warsaw agglomeration [18]. In past financial perspectives, as well as in the current one, one element is the development of energy companies including their development and transformation in favour of renewable 
energy sources based on: hydrogen, wind, solar, water, biomass, biogas, geothermal, and decarbonised gases.

The pattern of energy acquisition from renewable sources for Poland results from its specific geographical conditions and utilisable resources. In 2019, the energy extracted from renewable sources in Poland came predominantly from solid biofuels $(65.56 \%)$, wind energy $(13.72 \%)$ and liquid biofuels $(10.36 \%)$ with the combined energy value extracted primarily from renewable sources amounting to 396,498 TJ. Overall energy consumption from renewable sources between 2015 and 2019 increased by 8.80\%, i.e., from 381,129 TJ in 2015 to 414,682 TJ in 2019. During the same period, the gross final energy consumption from renewable sources increased by 15.57\%, i.e., from 325,387 TJ in 2015 to 376,063 TJ in 2019. The share of renewable energy in the final energy consumption of the 28 EU countries and Poland was 9.9\% and 7.7\%, respectively, in 2018. Between 2015 and 2018, there was an increase of 0.7 p.p. for the EU-28 and a decrease of 0.2 p.p. for Poland. In 2018, the share of renewable energy in the total primary energy was $14.7 \%$ for Poland and $30.9 \%$ for the EU-28. The average annual growth rate of this indicator from 2015 to 2018 was 3.5\% for Poland and 3.9\% for the EU-28 [19]. Wind farms and solar power plants contribute the most to Poland's overall electricity balance. Poland benefits the most from these RES sources. The remaining renewable sources are only marginally exploited (Figure 1) [20].

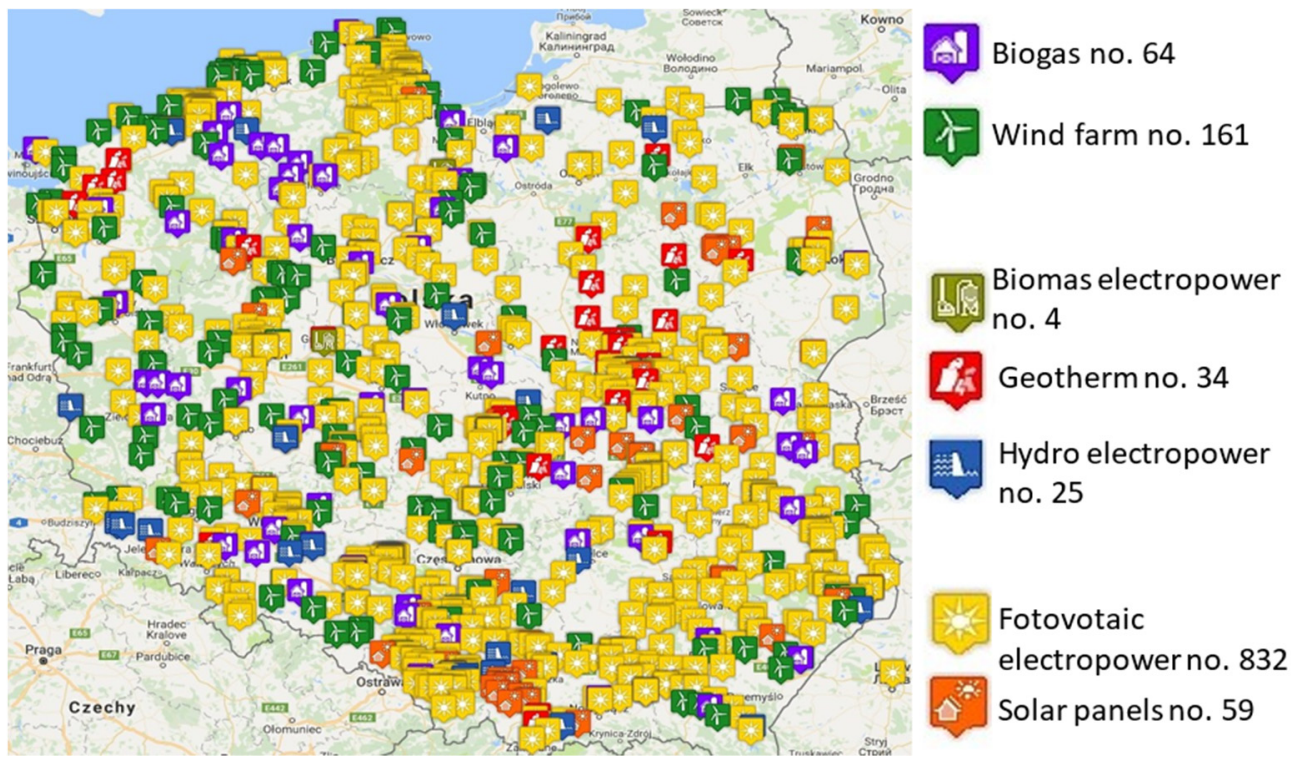

Figure 1. Distribution of renewable power installations in Poland.

The analysis of the energy sector undertaken in this article focuses on the issue of the energy portfolio and the forecast of its changes in one of the poorest areas of the European Union, the macroregion of Eastern Poland [21]. With the exception of the Świętokrzyskie Province, the remaining ones, Podlaskie, Warmińsko-Mazurskie, Lubelskie, and Podkarpackie, are located on the external border of the European Union. In 2018, these provinces were in a group of nine out out of sixteen provinces/regions (next to KujawskoPomorskie, Opolskie, Lubuskie and Zachodniopomorskie), which, in comparison to other Polish provinces, were characterised by the lowest level of socio-economic development measured by gross domestic product (GDP) per capita in PLN (Figure 2) [22]. 


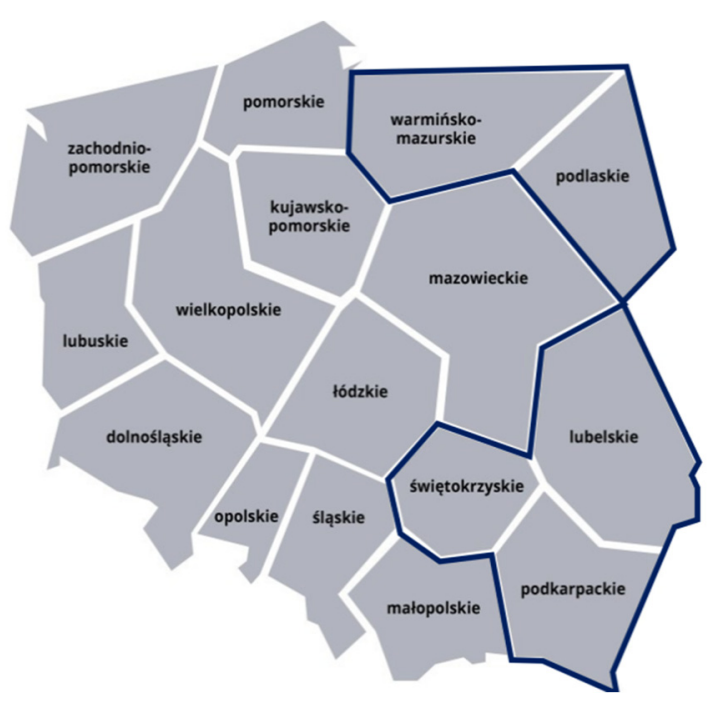

Figure 2. Eastern Poland macroregion.

Despite the persistence of a lower level of socio-economic development in the abovementioned provinces over the past 20 years, including in the development of the energy sector [23], an improvement in the socio-economic indicators of this part of the country has been noticeable, which testifies to a steady development trend. One of the factors influencing the positive changes in the development of the aforementioned provinces is the guarantee of funding for investments since 2007 available from EU resources through the Operational Programme Eastern Poland [24]. However, despite their proper utilisation, the level of financial investment in changes to the energy portfolio is still relatively small [25].

Referring to the macroregion of Eastern Poland, its transformations in terms of the acquisition and distribution of energy, the article adopts three research objectives:

1. The identification of conditions and premises for transformation of the energy portfolio of the Eastern Poland macroregion, and of its individual parts-provinces;

2. A forecast of the courses of evolution of the energy portfolio of the Eastern Poland macroregion triggered by the necessity to implement the Green Deal of the European Union by 2030;

3. Recommendations for the energy transformation of the Eastern Poland macroregion.

The article formulates a hypothesis, that the energy transformation of the Eastern Poland macroregion will be implemented by successive transformations of the energy portfolio towards dispersed energy sources, and the development of a local, prosumer energy sector.

Research on portfolio optimization from various perspectives focusing on a selected development trend is a relatively new issue [26]. They essentially focus on identifying a portfolio optimization [27]. In this respect, it is possible to indicate items that compare the structures of financial interdependencies [28], as well as their correlations with the energy sector [29]. Moreover, taking into account renewable energy sources in the climate security projection [30].

However, there are no results in the subject literature regarding the area of the aggregated energy portfolio of the Eastern Poland macroregion. The shaping of a new energy portfolio may thus constitute an opportunity for a just transition in this part of the EU in the management processes [31]. Moreover, it may favor the ecological transformation of the macroregion's development [32] which is characterised, compared to other EU regions, by relatively low GDP per capita values and energy poverty. The undertaken research correlates the practical knowledge in the field of shaping the new energy portfolio of the European Union with that covering its individual parts. 


\section{Theoretical Approach}

The Eastern Poland macroregion and its transformation towards renewable energy sources are considered through the prism of energy portfolio change which is formed by both renewable energy resources (RES) and non-renewable energy resources, as well as the structure of their acquisition in the indicated region. Seven renewable energy sources are considered here: wind energy, solar energy, hydroelectric energy, as well as geothermal energy, energy from biomass and biogas/bioenergy, energy from decarbonised gases-biomethane, LNG, CNG, energy from cogeneration, and energy from hydrogen. In addition, the three conventional fossil fuel-based energy sources used to date, i.e., coal, gas and crude oil, are considered. The energy sources identified are both a real and a potential resource. In the latter case, it may be used in the process of shaping the energy system in particular regions of the Eastern Poland macroregion. For each of the energy sources identified, there are specific technical, technological, economic and political constraints of a widely differing character. In addition, there are specific social reasons that will influence the positive perception and implementation of a given energy source within the region or, conversely, will hinder or prevent its use and the construction of the related technical infrastructure. The indicated energy sources already have developed and tested industrial technologies for their implementation in the Eastern Poland macroregion, with the exception of hydrogen, which has so far not been used.

To determine the current and future energy portfolio of the Eastern Poland macroregion, the Boston consulting group matrix, also called the growth-share matrix [33] (p. 238), was used. The theoretical approach of the BSC method is widely described in literature by, among others, R. Lynch [34] (pp. 176-177) and E. Segev [35] (pp. 155-156), as it has become the starting point for the construction of other matrix methods of analysis and strategy design. The matrix created by Bruce D. Henderson in 1970 [36] was designed to help corporations position their business units and/or manufactured products.

Based on this method, the location of the energy source in the portfolio was defined as follows:

- The availability of energy sources (renewable and non-renewable, wind, solar, water including geothermal, biomass and biogas/ bioenergy, decarbonised gas energybiomethane, LNG, CNG, cogeneration, hydrogen and fossil fuels, coal, gas and oil);

- The expected life cycle of the energy production technology used and the phase it is currently in (it was assumed that this depends on the development possibilities of the technology, the degree of standardisation, the universality of solutions, and the legal and financial conditions resulting from the implementation of the European Green Deal) [37-39];

- The financial resources required and the efficiency of their use over time.

The adopted method made it possible to develop an energy portfolio for the Eastern Poland macroregion, which includes four categories of energy sources:

- D-a baseline source, i.e., a still widely used source with diminishing impact due to declining usage. In the BCG matrix they are situated in the dogs field (also called: ball, ballasts, lame ducks);

- CC-key source, which is the primary source of energy supply for the region and is at a mature stage and not requiring large investments. In the BCG matrix, they are located in the cash cow field (also called: golden hens);

- S-a key source which forms the core of the region's energy supply, but which is still in the development phase and thus requires considerable financial investment. In the BCG matrix, they are positioned in the field of stars (or hits);

- $\quad$ QM-experimental source - which is in its infancy, with high financial needs and poor results, but indicating that it will become a key source for the region in the future. In the BCG matrix, they are positioned in the field of question marks (or problems, difficult children, wildcats). 
Analysis of the placement of energy sources resulted in two portfolio options:

- A balanced portfolio including sources categorised as 'cash cow' and 'mature stars'. These represent the main source of energy supply and will continue to be developed to ensure the continuity of entities operating in the region. Furthermore, conditions are being created for the development of new energy sources in the region;

- An insufficient portfolio, which could take the form of a declining portfolio or a fledgling portfolio. A declining portfolio can provide business continuity for entities operating in the region, but is undevelopable and, in the long term, could threaten the region's energy security. Conversely, the fledgling portfolio is developable but is unsustainable and thus could lead to liquidity crises.

The proposed portfolio approach using the BCG matrix for the macroregion is a new proposal. It is performed in relation to business units, including energy [40]. Currently, the benchmark concept is widely used in the analysis of the energy portfolio, which allows for the assessment of energy supply costs [41,42], related to the sustainable approach [43,44].

The paper also uses an extended PEST method and a scenario-based approach $[45,46]$. Predictions of changes in the energy portfolio of the Eastern Poland macroregion were made within the framework of four analytic perspectives defined by the framework of the extended PEST model-PLRTEEESETI (strategic planning tool). This involves forecasting changes in factors in the following areas:

1. Political, including aspects of the political, legal, regulatory, and of time;

2. Economic, evaluating aspects of the economic, environmental, and ecological;

3. Social issues, in terms of problems: social, ethics;

4. Technological, analysing technological development, infrastructure.

The factors generated from the analytical framework were evaluated in the context of the trends defined in the article: growth, stabilisation and regression. An impact strength projection from -3 to +3 was used here, taking into account the level of probability of a phenomenon occurring in a given area. The application of this analytical approach made it possible to determine the influence of the environment on the development of the energy portfolio of the Eastern Poland macroregion in the context of 2030. A scenario approach was applied to separate analytical perspectives and to forecast changes in the energy portfolio of the Eastern Poland microregion [47].

In the subject literature there are many extensions of the PEST method, for example:

- PESTLE (political, economic, socio-cultural, technological, legal and environmental) [48];

- $\quad$ PMESII-PT (political, military, economic, social, information, infrastructure, physical environment, time- used in military terms);

- STEEPLE (social, technological, environmental, economic, political, legal, ethical) [49];

- STEEPVL (social, technological, economical, ecological, political, values and legal) [50] (p.110);

- PRESTCOM (in addition to political, regulatory, economic, social, technological factors, it also includes competitive, organisational and market factors) [51] (p. 120).

However, we do not find the proposed coverage in the PLRTEEESETI extension with regard to energy issues. A similar solution is proposed by the PESTEL method of scanning the environment [52], but it does not include factors such as time or ethics.

Scanning the environment in this way aims to: detect trends and patterns important for the institution depending on the adopted perspectives; define potential threats, opportunities, or changes for the institution implied by those trends and events, promoting a future orientation in the thinking of management and staff, and alerting management and staff to trends that are converging, diverging, speeding up, slowing down, or interacting [53].

The identification of the energy sources constituting the current energy portfolio of the macroregion of Eastern Poland and the analysis of its development until 2030 was made on the basis of three types of research sources: 
- $\quad$ Records of strategic documents (e.g., regional development strategies) of the analysed voivodships/regions of the Eastern Poland macroregion, which are announcements of undertaken initiatives;

- $\quad$ Subject literature reflecting investment trends in the region;

- The results of surveys conducted among a carefully selected group of decision-makers: five provincial governors as the administrative authorities on the ground (the marshal is the chair of the provincial assembly, the executive body of the regional government) and three representatives of the municipal associations.

A questionnaire-based survey was carried out. The questionnaire comprised 37 questions, including two key questions. They covered the following analytical perspectives: political-12 questions, economic -9 , social -5 , technological -12 . The questions were closed-ended and were designed using a nominal and ordinal scale. The questionnaire included:

- $\quad$ Eight single-response questions (single response and multi-alternative);

- $\quad$ Six questions requiring the selection of several answers (multi-alternative);

- $\quad$ Six questions needing to establish a ranking and probabilities;

- Fifteen questions requiring an evaluation of the categories included in them in terms of trends and the likelihood of specified phenomena occurring. Their use enabled us to determine the development prospects of the energy portfolio in 2030.

A diagrammatic illustration of the research results, using pie and bar charts and tables, was adapted according to the type of data captured. The questionnaire was prepared and made available using Microsoft ${ }^{\circledR}$ Forms. Microsoft ${ }^{\circledR}$ Excel 2010 was used to analyse the research material.

The research questionnaire was a pilot study, and its results will enable the authors to extend the research to other local authorities located in the given macroregion, economic entities, inhabitants, including prosumers, in its subsequent stages.

The aim of the research was to develop recommendations for regions that align themselves with the European Green Deal strategy, including the creation of a closed-loop economy of "green" jobs provided by "green" consumption and the disposal of its residues in a "green" cycle of energy extraction and use. Moreover, a planned outcome of the research is to define an energy portfolio for the provinces of Eastern Poland participating in the study [54].

\section{Results}

The undertaken research identified prerequisites and considerations for the transformation of the energy portfolio of the Eastern Poland macroregion. It was conducted through an institutional legal analysis and identification of the region's potential energy portfolio, projecting its change over time.

\subsection{Determinants and Prerequisites of Energy Portfolio Transformation in the Eastern Poland Macroregion-Questionnaire Results}

The most important prerequisites that the representatives of the surveyed entities drew attention to, and which are expected to guide them in choosing the direction of energy policy changes in a given region, include: (1) economic, (2) social, (3) geographical/environmental, (4) infrastructural, and (5) legal. In these cases, the respondents anticipate:

- The occurrence of particularly unfavourable macroeconomic changes (e.g., an increase in inflation, an increase in lending interest rates, increased unemployment, lowering of the economic growth rate) which will impede the development of green energy, with the greatest likelihood of a negative upward trend;

- A positive upward trend of the structural factor and the state of the economy influencing the development of the energy system, but there were fears of a downturn despite the low probability of this happening; 
- Providing financial support for the development of renewable energy sources (Figure 3). Among the investment directions for which financial support was declared were investments in: solar energy, biomass and biogas energy, wind energy, followed by hydrogen, cogeneration and hydropower; the least mentioned was energy from decarbonised gases. It should be noted that these lines of investment are almost identical to those currently being pursued, namely in solar energy, wind energy, biomass and biogas energy, and energy from cogeneration, hydrogen and water, and least often from decarbonised gases;

- The emergence of an upward trend with a potentially positive impact on government support (financial, organisational, legal) for energy development in the region. However, the range of opinions in this area indicates the volatility of this factor, which should be seen as a threat to the development of the energy system. It is worth noting that the surveyed representatives indicated the need to prioritise financial, legal, and organisational support for transforming the energy portfolio;

- That there will, in all probability, be an upward trend with a potentially positive impact in the availability and use of renewable energy sources;

- A high level of commitment in the area of public consultations on planned energy policy changes (Figure 4), a high acceptance of activities aimed at disseminating information on energy policy changes (Figure 6), and low or medium acceptance by residents for the creation of RES installations near their place of residence (Figure 7);

- Most likely a downward trend with a potentially positive impact on environmental pollution from non-renewable energy sources, which in turn will positively influence the direction of energy policy in the region. However, the spread of opinion in this regard was considerable, indicating the high degree of uncertainty for this factor;

- A tightening of the requirements to meet environmental standards and norms, including ISO, with the potential for negative impacts resulting in a slowing down of the momentum of energy policy changes in the region;

- In the area of infrastructure, the development of greater energy independence for the region, based on the existing but upgraded model of the energy network (Figure 5);

- An upward trend with a positive impact on the formation of groups-cooperatives, including energy clusters-fostering the development of distributed energy in the region.

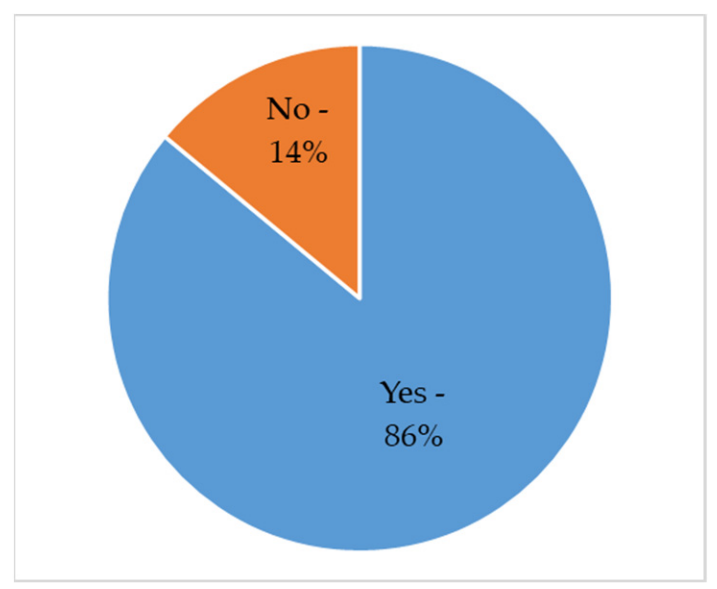

Figure 3. Selected survey results-an analytical-economic perspective: do you foresee that the province will provide financial support for the development of energy production from renewable sources (RES)? 


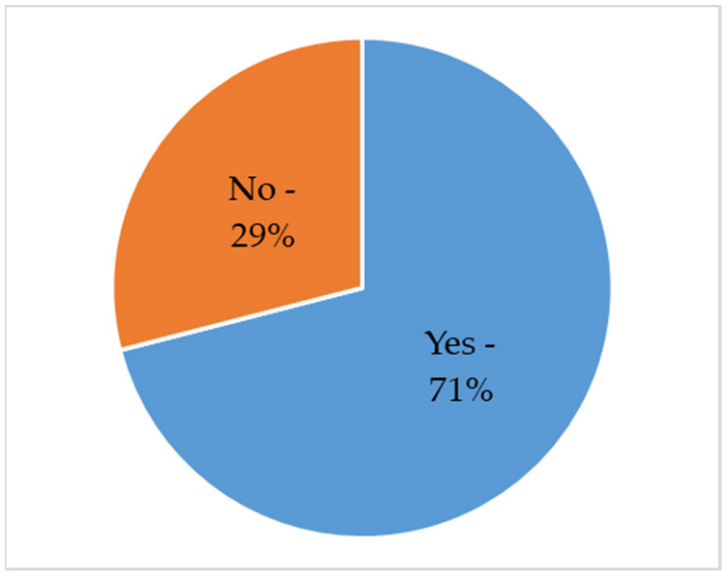

Figure 4. Selected survey results-an analytical-social perspective: are public consultations expected for the planned changes in energy policy in your province?

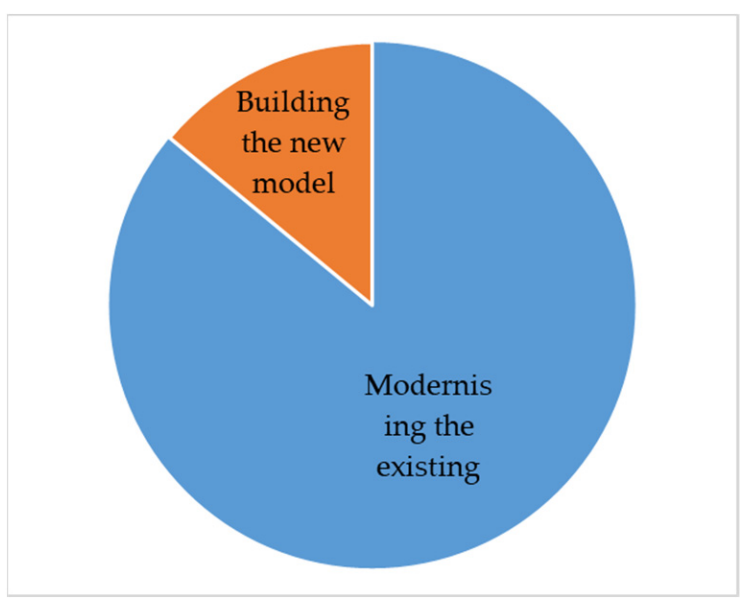

Figure 5. Selected survey results—an analytical-political perspective: in your opinion, would it be appropriate to build on the current/existing model of energy networks or should a completely new model be built?

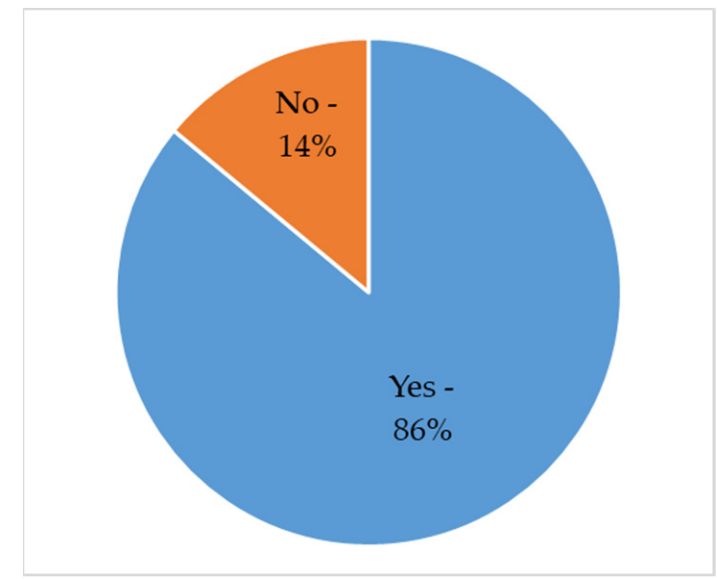

Figure 6. Selected survey results - an analytical-social perspective: are there any activities planned to publicise the changes in energy policy in your province? 


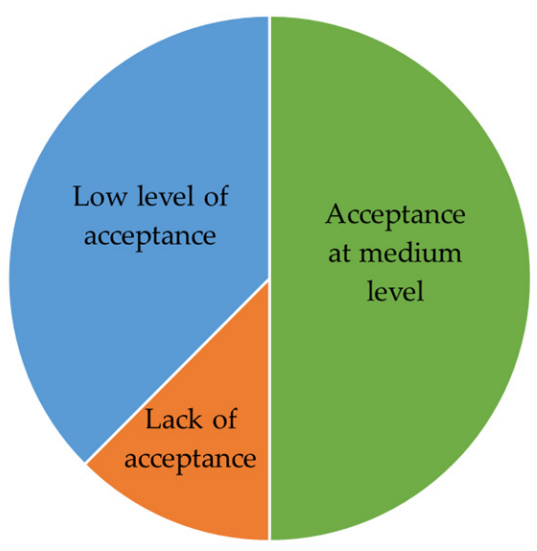

Figure 7. Selected survey results-an analytical-social perspective: how do you assess the level of acceptance by the residents of your province for the creation of RES installations (other than prosumer installations) near their place of residence?

It should be noted that in the opinion of representatives of local and governmental authorities, the political factor does not influence changes in the process of transformation of the energy sector in the provinces (Figure 8). They state that the current energy system in the province can be considered effective in the following areas: consumption, generation, transmission, distribution and storage, respectively (Figure 9). They see the European Union's Green Deal policy as a document that fits neatly into the trends of environmentalism, liberalism and an ideologically neutral programme. The implementation of its objectives, in the opinion of the respondents, will impact to a high and medium extent on the energy security of the Eastern Poland macroregion (Figure 10).

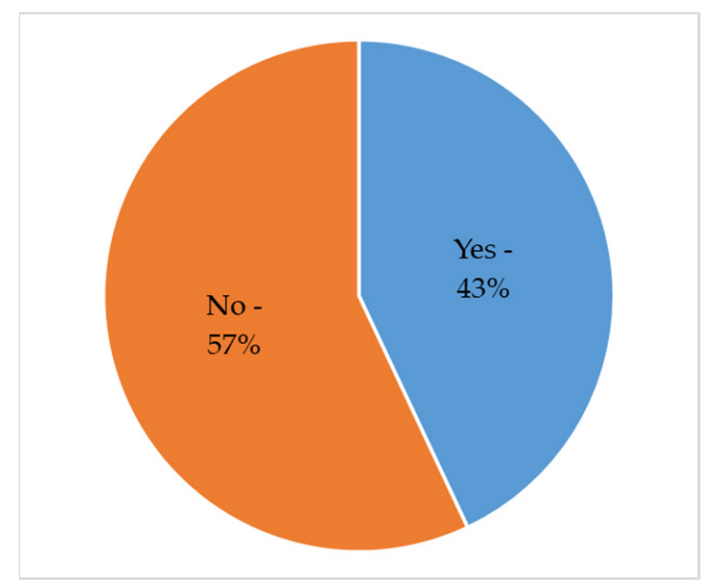

Figure 8. Selected survey results-an analytical-political perspective: are there changes currently planned in the strategic documents of the province's development that would lead to the implementation of the European Green Deal? 


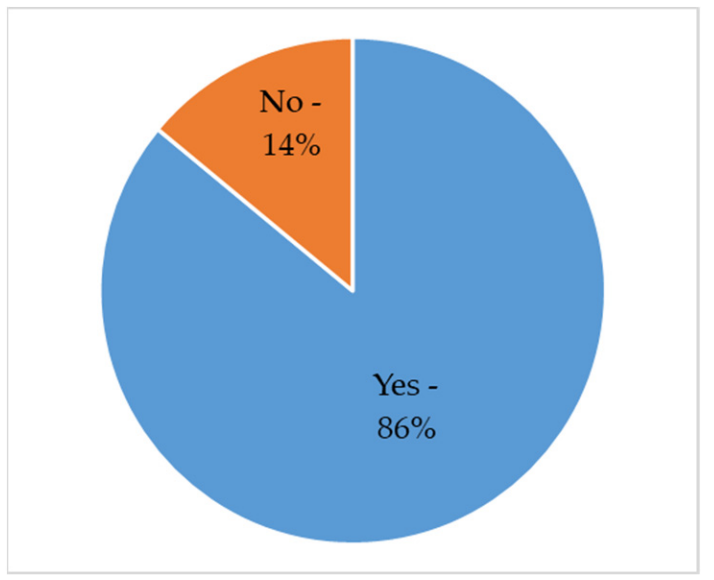

Figure 9. Selected survey results-an analytical-economic perspective: can the current energy system, in the province you represent, be considered effective as far as your area is concerned?

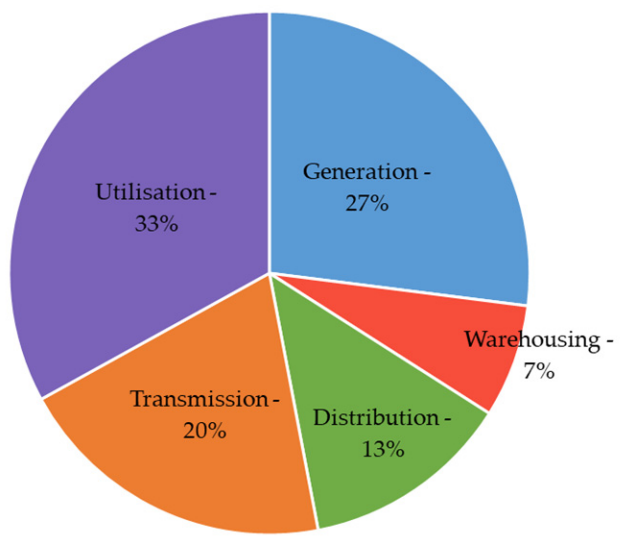

Figure 10. Selected survey results-an analytical-political perspective: do you intend to make changes to the province's energy policy in order to make it more energy independent?

3.2. Potential Energy Portfolio for the Eastern Poland MacroRegion-Results of Institutional and Legal Analysis

The research analysed provisions in strategic documents of the regions/provinces constituting the Eastern Poland macroregion within the scope of activities planned by them in the energy sector. Reflecting the challenges presented in the Commission's Communication, the European Green Deal addresses the energy sources used to date, the pathways for their transformation, to provide clean, affordable and secure energy and measures to save energy and resources [55]. Among the documents analysed were: provincial development strategies, regional innovation strategies, territorial (provincial/regional) contracts covering the years 2014-2020, as well as the years 2021-2027, in relation to the duration of the next financial period of the European Union.

The interpretation of documents influencing the development of the energy sector in the Eastern Poland macroregion takes into account perspectives of the European Union institutions conditional on inter alia documents derived from the European Green Deal policy, including the "Fit for 55" package, determining for example the prices of $\mathrm{CO}_{2}$ emission allowances, or carbon tax in the carbon border adjustment mechanism-CBAM [56]. At the national level, the region's energy development activities will be influenced by documents such as: the Farm-to-Fork Strategy, the Roadmap for a Closed Cycle Economy, the Hydrogen Strategy, the Smart Cross-Sectoral Integration Strategy, the Climate Pact or the Just Transition Fund [57], and the National Recovery and Resilience Plan (KPO) [58]. Furthermore, the strategic documents of individual provinces of the Eastern Poland macroregion take into account specific characteristics of the given region, including: geographical lo- 
cation, climatic conditions, current energy infrastructure, investment opportunities in the region and social conditions.

The legal and institutional analysis shows that the energy portfolio of the macroregion of Eastern Poland in 2030 can be diversified and balanced; this is a result of the different potentials of the analysed provinces. The potential portfolio can be considered as valid for the energy transition phase. The conclusions of the analysis do not indicate that this is a declining portfolio. An analysis of the documents relating to energy obtained from fossil fuels shows a declaration of sustained use, which places them in the cash cow field. Poland's declared increase in the use of energy from blue fuel up to 2030 will be almost fivefold (from $14 \mathrm{TWh}$ to $54 \mathrm{TWh}$ ) [59]. This entails the development of gas-fired power plants, which will primarily affect the energy potential of the Podkarpackie province. With regard to energy from renewable sources, this is a young portfolio, and the energy sources can be placed in the stars field, as the growth dynamics of energy production from renewable sources can be strong.

As a result of the conducted questionnaire-based research, it was found that the respondents are divided on the subject of amending strategic provincial development documents aimed at implementing the European Green Deal. Nevertheless, despite this declaration, in a further response, respondents stressed that the European Green Deal policy influences the actions of the territorial unit they represent. All surveyed representatives have declared changes in the energy policy of the provinces directed towards their greater energy independence.

The projected portfolio of energy sources for the Eastern Poland macroregion for 2030 was prepared based on the analysis of the provisions in the strategic documents of individual regions, Table 1 [60-67].

With regard to the regions of Eastern Poland, the analysis covered the provisions of the voivodship development strategy, regional smart specializations and territorial contracts in the field of energy development, in particular in the pro-ecological direction. When preparing a synthetic summary of the forecast portfolio of energy sources, the results of the SWOT analysis included in the documents of individual regions were used.

The development strategy for the Warmińsko-Mazurskie province emphasises the importance of securing energy conditions for the achievement of strategic goals [60]. The province is a national leader in terms of the share of energy produced from RES in the total energy production. However, the high value of this indicator is a consequence of the low level of its own energy production. The province is dependent on external energy production, with only a small amount of hydroelectric power being generated within its borders. The strategy emphasises that the development of the province is conditional on investment in gas and electricity distribution networks and the use of renewable energy sources, ultimately aiming for the region to become as self-sufficient in energy as possible [61].

SWOT analysis of the strategy identified shortcomings in the energy infrastructure in terms of distribution network and transformer/distribution substations and high energy prices (weaknesses). Opportunities in the energy area highlighted the government's implementation of planned investments in power and gas infrastructure. Weaknesses identified in the list of threats were in the system of government development instruments, in particular the lack of opportunities for the development of the prosumer energy sector.

Among the measures which are to support the achievement of the planned objectives, the following are forecast: the modernisation and construction of a gas distribution/transmission network, the creation of IT systems to support network management and operation; modernisation to optimise network parameters; the improvement of energy efficiency in the region; developing infrastructure for electromobility; the creation of low-emission heat sources based on RES, the creation of low-emission efficient heat and energy sources (co-generation); creation of efficient heat networks and nodes and modernisation of inefficient ones; automation of the heating process; the construction of modern installations based on RES energy, including geothermal energy (ibidem, 61). 
The territorial contract provides for projects in the field of energy efficiency improvement, energy grid development and thermomodernisation of public buildings [62].

Table 1. Forecast energy sources portfolio for the provinces of Eastern Poland for the year 2030results of legal and institutional analysis.

\begin{tabular}{|c|c|c|}
\hline \multirow{2}{*}{ Energy Source } & \multicolumn{2}{|c|}{ Location in Energy Portfolio * } \\
\hline & \multicolumn{2}{|c|}{ In 2030} \\
\hline \multirow{2}{*}{ Solar energy } & $\mathrm{S}$ & $\mathrm{QM}$ \\
\hline & $\mathrm{CC}$ & $\mathrm{D}$ \\
\hline \multirow{2}{*}{ Wind energy } & S & $\mathrm{QM}$ \\
\hline & $\mathrm{CC}$ & $\mathrm{D}$ \\
\hline \multirow{2}{*}{ Hydropower } & $\mathrm{S}$ & $\mathrm{QM}$ \\
\hline & $\mathrm{CC}$ & $\mathrm{D}$ \\
\hline \multirow{2}{*}{ Bioenergy } & S & $\mathrm{QM}$ \\
\hline & $\mathrm{CC}$ & $\mathrm{D}$ \\
\hline \multirow{2}{*}{ Energy from decarbonised gases } & $\mathrm{S}$ & $\mathrm{QM}$ \\
\hline & $\mathrm{CC}$ & $\mathrm{D}$ \\
\hline \multirow{2}{*}{ Energy from cogeneration } & $\mathrm{S}$ & $\mathrm{QM}$ \\
\hline & $\mathrm{CC}$ & $\mathrm{D}$ \\
\hline \multirow{2}{*}{ Energy from hydrogen } & $\mathrm{S}$ & $\mathrm{QM}$ \\
\hline & $\mathrm{CC}$ & $\mathrm{D}$ \\
\hline \multirow{2}{*}{ Energy from fossil fuels/coal } & $\mathrm{S}$ & $\mathrm{QM}$ \\
\hline & $\mathrm{CC}$ & $\mathrm{D}$ \\
\hline \multirow{2}{*}{ Energy from fossil fuels/natural gas } & S & $\mathrm{QM}$ \\
\hline & $\mathrm{CC}$ & $\mathrm{D}$ \\
\hline \multirow{2}{*}{ Energy from fossil fuels/crude oil } & $\mathrm{S}$ & $\mathrm{QM}$ \\
\hline & $\mathrm{CC}$ & $\mathrm{D}$ \\
\hline
\end{tabular}

* Legend: QM—experimental nascent phase/question marks; S—key development phase/star/stars; CC—key phase at maturity/cash cow; D—baseline dying phase/dog/dogs.

In the development strategy for the Podlaskie province, two energy-related strategic objectives have been identified: competitive economy and quality of life. The vision of the province defined in the strategy emphasises that it is to be green, open, enterprising and accessible. The activities undertaken in the province are to be targeted at renewable energy sources, the production of equipment for energy generation from RES, and ecological and energy-efficient construction. In terms of energy production, the province has identified production opportunities from biogas, including: waste management, animal and food production (mainly dairy); wind energy (especially in the northern part of the region); and solar energy [63]. The strategy emphasises that the RES development underpins both the region's energy security and climate protection. Consequently, a decentralised model of energy production, located in rural areas and based on RES, has been adopted in the province, which corresponds to the economic structure of the region, dominated by agriculture and agri-food processing, which also provides by-products requiring appropriate management [63]. In the SWOT analysis of the strategy, the strengths of the province include good possibilities for the production of heat and electricity from biogas and relatively good conditions for the development of wind and solar energy. The lack of energy security in the province (dependence on electricity imports, the province registers the lowest values in the country for energy production), a weak and outdated power grid and the insufficient capacity of the gas grid were identified as weaknesses $[62,63]$. Opportunities highlighted 
were energy investments in the $400 \mathrm{kV}$ electricity and gas distribution and transmission networks, as well as important legislative changes in the energy and waste management sectors. Conversely, the disadvantageous location of wind power plants was identified as a threat to the region's nature conservation in terms of the Natura 2000 programme. Among the activities undertaken in the province, the following are highlighted: projects reducing the levels of both energy and material consumption and those based on renewable sources of energy (in which the province records above average results) and combined heat and power technologies (co-generation). In the next development strategy adopted by the province, one of the strategic objectives is a dynamic economy, for which the more detailed, in the context of energy, operational objective is energy revolution and a closed-loop economy [64]. Among the activities envisaged in the province under these objectives are the development of circular economy technologies and energy production from renewable sources, as well as the continuation of activities defined in the previous period. To increase the energy security of the province, the territorial contract provides funding for projects aimed at modernising electricity distribution and transmission systems [65].

The need for effective use of the region's resources, including energy resources and natural conditions for agriculture, and striving to improve energy efficiency were highlighted among the development challenges presented in the strategic documents of the Lubelskie province. In order to increase energy efficiency, investments are needed to modernise, reducing the failure rate of systems, as well as the losses in energy transmission and, in addition, investments enabling the integration of different energy sources, including renewable energy sources. Among the planned activities, the local authorities have foreseen the following: the modernisation and development of local energy networks; the expansion and modernisation of the dispersed energy system; the rationalisation of the exploitation of mineral resources; the construction of technical infrastructure, the preparation of investment areas in the mining and energy sectors, as well as the construction of facilities and equipment for the transmission of energy to the national energy system from the planned conventional power plants and from dispersed sources (RES), the reclamation of former mining areas and the mitigation of the negative effects of mineral deposit exploitation [66]. The Lubelskie Province Development Strategy to 2030 maintains the existing lines of activity related to the pursuit of increased energy efficiency and increasing the use of energy from renewable sources [67]. It also stressed the need to implement measures to develop the energy generation, distribution and storage system and the monitoring of its transmission. In addition, the development of low- and zero-emission generation capacity and distributed energy generation based on prosumers, sustainable waste management, recycling and recovery of raw materials and energy have been identified as important policy directions. The area of the province, in particular Polesie Lubelskie and the Bug River basin, was indicated as having excellent potential for the exploitation of solar energy. At the same time, the development of new RES-based generation capacity is planned by using mining brownfield sites, as exemplified by the state of North Rhine-Westphalia [68]. In the Lublin Province Development Strategy to 2030, special attention was paid to hard coal resources available in the Lubelskie Coal Basin which constitute $18.1 \%$ of national resources. Currently, coal is exploited from the Bogdanka deposit, while another two deposits are being prepared for exploitation (area K-3; Ostrów). The strategy emphasises the search for new solutions for hard coal as a raw material for on-site energy production. Lubelskie Province's share of energy produced in the country in 2019 was only $1.5 \%$ (ranked 14th in the country). Energy generation was dominated by thermal power plants $(62.7 \%)$, industrial power plants (36.9\%) and renewable energy sources $(22.9 \%)$. A total of $20 \%$ of the province's energy demand is met from sources within the province and $80 \%$ from sources outside the region (ibidem, 67). In the search for factors dynamising socio-economic development in the regional innovation strategy of the Lubelskie province, four smart specialisations/branches have been defined. Two of those identified are closely related to energy: 
- Low-carbon energy, including conventional energy based on coal and gas (including shale gas), as well as unconventional energy — energy from biomass, solar, wind and water;

- The bioeconomy, which involves the production of energy crops and the extraction and use of energy from renewable sources (biorefineries, biofuels). The reserves of agricultural land that can potentially be used to grow annual energy crops have been estimated at around 280,000 ha in the province [69].

One of the operational goals in the Świettokrzyskie province is to ensure energy security and to provide customers with the possibility of switching energy carriers [70]. Particular attention was paid to the implementation of investments enabling the use of renewable energy sources (solar, wind, water, including geothermal, biomass) and the issue of utilising energy sources in accordance with the conditions and possibilities of energy acquisition. In this context, an important element is also the production and adoption of equipment automation to achieve a favourable energy mix. The province has a conventional block power plant in Połaniec which participates in securing the energy needs of the country (indicated as a strength in the province). Since 2004, the power station has been operating a biomass energy production facility using shrub willow from energy plantations in the province [71]. There are also renewable energy sources in the province which exploit water and wind energy. Substantive support for the use of RES in the region and the optimisation of energy management is provided, amongst others, by the Świętokrzyskie Centre for Innovation and Technology Transfer [72]. The province is developing cooperation with other provinces in, among other things, the use of natural geothermal resources. As in other provinces, activities are being undertaken in the expansion and modernisation of electricity transmission grids and distribution networks, the development of the production of plants for energy purposes, increasing energy efficiency of public utility buildings, as well as the construction of an energy storage system, the development of new technologies for obtaining energy from renewable sources and the use of this energy in tourist and public facilities [73]. One of the goals set for the province is to increase the efficiency of energy management, promote sustainable energy consumption and popularise solutions that are beneficial in terms of caring for the environment. Moreover, the strategy emphasises the need to minimise the negative impact of infrastructure development on the landscape (example: photovoltaic farms and technologies to protect birds from the so-called "water mirror effect") as well as indicating the conditions for regional self-sufficiency, including the appropriate choice of renewable energy sources. Within the smart specialisations of the Świętokrzyskie province, in particular: modern agriculture and food processing and resource-efficient construction. The following activities connected with the energy sector have been identified: the production of biofuels [74]; the optimisation of methods of utilisation of by-products and waste (industrial, construction, agricultural, municipal); the use of machines and equipment in agriculture that reduce energy and water consumption; the use of materials and technologies in construction that contribute to the improvement of the energy efficiency of buildings, reduction of energy consumption; powering buildings with energy from renewable sources; and scientific research and development work aimed at, for example, creating materials that make it possible to increase the energy efficiency of buildings [75]. In addition to these, other sub-sectors were identified within specialisations, such as: prosumer energy development; energy from waste, alternative fuels and environmental protection (use of waste hydrocarbons and hydrogen), and the use of RES in transport. Among the undertakings included in the territorial contract, connected with the energy sector, the following have been defined: support for actions in energy sector efficiency; thermal modernisation of educational establishments and the creation of a LowEmission Technologies Centre (experimental and implementation centre in construction and industrial production; territorial contract for the Świętokrzyskie province).

One of the strategic objectives of the Podkarpackie province is to develop the infrastructure for the growth and optimisation of the use of natural resources and energy while protecting the natural environment. This is further specified in the operational objectives, 
namely: the development of energy infrastructure; the rational use of energy; and support for RES-based energy. Among a number of measures defined in the strategy to be implemented, the following have been identified: expansion and modernisation of the transmission, and distribution (primary and secondary) networks, and the improvement of the efficiency of their components [76]. Modernisation and expansion also includes district heating networks in towns and cities and is especially intended to reduce the number of households that burn coal. The province has natural gas deposits ( $40 \%$ of national gas) and thus measures are being implemented to increase the possibility of acquiring, transporting and distributing this resource and to increase the capacity of underground gas storage. Further investments are being made to identify new reserves and quantify the size of existing reserves [77], as well as to support high-efficiency cogeneration networks with the use of natural gas. The province has good natural conditions for the development of RES infrastructure, including solar, water, and spacious areas of uncultivated agricultural land with the potential for the cultivation of energy crops. However, their use is restricted by environmental, social (for photovoltaic farms), formal and legal (for water power), and market factors (the domination of large entities-Połaniec Power Plant and Stalowa Wola Power Plant-limits the development of distributed energy) [78]. Measures are being implemented in the province to support the creation of RES micro-installations and prosumer activity in relation to companies and local government bodies. Solutions are being sought for efficient energy management in the area of distributed generation system development (Smart Grid). In addition, there are activities focused on implementing hydrogen technologies in energy production [79], increasing the energy efficiency of public and residential buildings, and promoting public awareness of the benefits of efficient energy use and renewable energy sources. The energy sector plays a complementary role within the smart specialisations identified in the region. With respect to the quality of life specialisation, support is given to projects that will harness alternative energy sources and help protect the environment; a similar role for projects in the province is to be fulfilled by the information and telecommunications specialisation [80]. In particular, within the first specialisation, activities focus on: RES-based eco-technologies (distributed energy, smart grids, wind turbines, water turbines, solar panels, biomass boilers, geothermal), energy-efficient and intelligent construction (passive, zero-energy, plus-energy houses), and biodegradable plastics. On the other hand, among the undertakings in the scope of energy, envisaged for financing in the territorial contract, the following were singled out: energy efficiency, support for the extension and modernisation of heating and cooling networks, thermal modernisation of artistic education establishments and, conditionally, an undertaking concerning research in the field of energy, information and communication technologies and mechatronics [81].

From the location of fossil fuel energy reserves, it results that in the analysed macroregion of Eastern Poland there are no lignite deposits, hard coal can be found in the Lubelskie province, and oil and natural gas in the Podkarpackie province. Consequently, the macroregion is supplied from conventional energy sources located outside the described area. Documents declaring the development of energy independence by provinces/regions, the location of conventional energy sources, provisions of the European Green Deal policy, "Fit for 55" package demonstrate the development of renewable energy sources in the macroregion of Eastern Poland. From the study of documents on the provincial level included as part of the studied macroregion, it emerges that all provinces are indicative of the development of RES, especially based on the use of solar radiation. The development of co-generation is pledged in particular by the Warmińsko-Mazurskie province. The Warmińsko-Masurskie province also exploits geothermal energy. In Podlaskie Province, it is worth noticing the fact of energy production from biogas, including waste management, animal and food production (mainly dairy). Furthermore, the province also plans to develop wind energy (especially in the northern part of the region). In the Lubelskie Province, the strategy envisages the development of energy from biomass, solar, wind and water (i.e., as in the previously mentioned provinces) and the use of conventional energy, 
based on coal and gas (including shale gas). In Podkarpackie Province, there are plans to create a "hydrogen valley", which will produce hydrogen from electrolysis using surplus electricity from RES [82].

\subsection{Potential Energy Portfolio of Eastern Poland Macroregion-Questionnaire Results}

Research indicating which energy sources in the voivodeship are currently supported financially, legally and organisationally primarily highlighted solar, wind, biomass and biogas energy as well as energy from cogeneration. The trend of retreating from outlays on energy obtained from natural gas, crude oil, decarburised gases, hard coal and lignite was also highlighted. In the area of the neutral support level, the remained energy sources derived from hydrogen, and with reluctant neutrality, derived from water and geothermal resources. The opinions on the need to support the development of energy sources until 2030 were similarly distributed. In this case also, respondents most often stressed the need to support the development of solar, biomass and biogas, wind and cogeneration sources. In this perspective, support for energy from biomass and biogas, hydrogen as well as water and geo-thermal resources is gaining importance (the distribution of respondents' answers is presented in Tables 2 and 3).

Table 2. Current priorities for financial, legal, organisational support of energy source development in the Eastern Poland macroregion.

\begin{tabular}{|c|c|c|c|c|}
\hline Location & Options & $\begin{array}{c}\text { First } \\
\text { Choice }\end{array}$ & صमा || & $\begin{array}{c}\text { Last } \\
\text { Choice }\end{array}$ \\
\hline 1 & Solar energy & & & \\
\hline 2 & Wind energy & & & \\
\hline 3 & Energy from biomas and biogas & & & \\
\hline 4 & Energy from cogeneration & & & \\
\hline 5 & Energy from hydrogen & & & \\
\hline 6 & Energy from water and geothermal sources & & & \\
\hline 7 & Energy from anthracite and lignite & & & \\
\hline 8 & Energy from decarbonised gases & & & \\
\hline 9 & Energy from crude oil & & & \\
\hline 10 & Energy from natural gas & & & \\
\hline
\end{tabular}

Table 3. Priorities of financial, legal, and organizational support for the development of energy sources in the macroregion of Eastern Poland in the perspective of 2030.

\begin{tabular}{|c|c|c|c|c|}
\hline Location & Options & $\begin{array}{c}\text { First } \\
\text { Choice }\end{array}$ & ص|| & $\begin{array}{c}\text { Last } \\
\text { Choice }\end{array}$ \\
\hline 1 & Solar energy & & & \\
\hline 2 & Energy from biomas and biogas & & & \\
\hline 3 & Wind energy & & & \\
\hline 4 & Energy from cogeneration & & & \\
\hline 5 & Energy from hydrogen & & & \\
\hline 6 & Energy from water and geothermal sources & & & \\
\hline 7 & Energy from decarbonised gases & & & \\
\hline 8 & Energy from anthracite and lignite & & & \\
\hline 9 & Energy from crude oil & & & \\
\hline 10 & Energy from natural gas & & & \\
\hline
\end{tabular}

Responses to questions concerning existing and future directions of support for the development of energy sources corresponded mainly to environmental and economic conditions in particular provinces/regions of the Eastern Poland macroregion, including: 
geographical location, natural resources, economic structure, industrial potential, the level of development of agriculture, which condition the development of a particular energy portfolio in those provinces. In this perspective, priority was given to the development of solar energy, biomass, biogas and wind energy. Hydrogen and cogeneration are less important for the development of energy sources in the region of Eastern Poland in the context of the macroregion's potential. The sources of energy derived from water and geothermal resources and decarbonised gases are ignored. (a comparison of the distribution of respondents' answers is presented in Tables 3 and 4). The indicated preferences allow for a clear picture of the directions of preferred changes until 2030 in the Eastern Poland macroregion.

Table 4. Development of energy sources in Eastern Poland resulting from potential growth determinants of the macroregion.

\begin{tabular}{|c|c|c|c|c|}
\hline Location & Options & $\begin{array}{c}\text { First } \\
\text { Choice }\end{array}$ & ש| & $\begin{array}{c}\text { Last } \\
\text { Choice }\end{array}$ \\
\hline 1 & Solar energy & & & \\
\hline 2 & Energy from biomas and biogas & & & \\
\hline 3 & Wind energy & & & \\
\hline 4 & Energy from cogeneration & & & \\
\hline 5 & Energy from hydrogen & & & \\
\hline 6 & Energy from water and geothermal sources & & & \\
\hline 7 & Energy from decarbonised gases & & & \\
\hline
\end{tabular}

The survey shows that, at present, fossil fuels are the key source of energy supply in the Eastern Poland macroregion, and they feature in the cash cow position within the BCG matrix. The use of energy from these sources is at a mature stage and does not require large investments. Because of their carbon footprint, by 2030 they will have moved into the area of a baseline source, i.e., a widely used source with a diminishing impact, being in a dying phase with diminishing effects. Which suggests that they are classified as dogs in the BCG matrix (Table 5). It is a natural process observed in many development areas in which new technology is discovered; there is a permanent change in the approach from the political, economic, environmental and social perspective. Modern technologies in the field of green energy (solar, wind, hydrogen, bioenergy or cogeneration) already allow for the creation of real alternatives in the area of energy sources necessary for the proper development of Poland and Europe. On the other hand, the New Green Deal, assuming the achievement of climate neutrality by 2050, is a breakthrough change of both political and economic nature. The current processes related to environmental protection, including the protection of the entire Earth, are yet another factor that determines the need to abandon the production of energy from fossil sources. If the mega-factor, being the man's responsibility for his actions as well as the emerging, universal social awareness that makes it necessary to eliminate factors threatening the planet inhabited by men, fossil fuels-as indicated by the respondents-will be eliminated in favor of renewable energy sources.

Looking ahead to 2030, respondents see a need to primarily develop solar energy, as well as biomass, biogas and wind energy. In the case of solar and wind energy, it can currently be classified as critical energy, which can underpin the region's power supply. The respondents attribute a slightly smaller role to bioenergy (biomass, biogas) and energy from cogeneration.

The indicated energy sources require significant financial outlays related to the implementation of investment processes. It is not only due to the construction of solar farms, wind farms, biogas plants or power plants producing energy from cogeneration but also to the entire energy system (transmission, distribution, storage, system management, security, etc.). 
In the BCG matrix these energy sources are located in the star field (S); however, the solar energy is modelled as a mature star ( $\mathrm{CC}$ - cash cow). The indicated position of these energy sources requires large financing both on the national and European levels, and perhaps global sources of financing as well. A significant amount of these funds should supply the investment processes. Some funds should also be allocated to development processes, including research. Such a procedure should make it possible to replace energy sources which in the BCG matrix are classified as dogs (D). In the case of solar energy, as well as wind energy, it should be noted that the indicated energy sources require also non-financial inputs. In the case of solar and wind energy, energy-producing devices will occupy a significant part of the Earth's surface (space on the Earth's surface) and interfere with natural and landscape structures. In this context, work should be undertaken to prepare relevant regulations and to take action in the social and cultural areas.

Hydropower, energy from decarbonised gases and energy from hydrogen, on the other hand, has been placed in the field of experimental sources, i.e., still in a nascent stage - characterised by high financial needs and poor results, but promising to become crucial for the region's performance in the energy sector of the future. In the BCG matrix, hydropower, energy from decarbonised gases and energy from hydrogen, occupies the status of question marks (QM) (Table 5).

Table 5. Forecast portfolio of energy sources for Eastern Poland macroregion for 2030—results of surveys.

\begin{tabular}{|c|c|c|}
\hline \multirow{2}{*}{ Energy Source } & \multicolumn{2}{|c|}{ Location in Energy Portfolio * } \\
\hline & \multicolumn{2}{|c|}{ In 2030} \\
\hline \multirow{2}{*}{ Solar energy } & $S$ & QM \\
\hline & $\mathrm{CC}$ & $\mathrm{D}$ \\
\hline \multirow{2}{*}{ Wind energy } & $\mathrm{S}$ & QM \\
\hline & $\mathrm{CC}$ & $\mathrm{D}$ \\
\hline \multirow{2}{*}{ Hydropower } & $\mathrm{S}$ & QM \\
\hline & $\mathrm{CC}$ & $\mathrm{D}$ \\
\hline \multirow{2}{*}{ Bioenergy } & $S$ & QM \\
\hline & $\mathrm{CC}$ & $\mathrm{D}$ \\
\hline \multirow{2}{*}{ Energy from decarbonised gases } & $\mathrm{S}$ & $\mathrm{QM}$ \\
\hline & $\mathrm{CC}$ & $\mathrm{D}$ \\
\hline \multirow{2}{*}{ Energy from cogeneration } & $\mathrm{S}$ & QM \\
\hline & $\mathrm{CC}$ & $\mathrm{D}$ \\
\hline \multirow{2}{*}{ Energy from hydrogen } & $\mathrm{S}$ & QM \\
\hline & $\mathrm{CC}$ & $\mathrm{D}$ \\
\hline \multirow{2}{*}{ Energy from fossil fuels/coal } & $\mathrm{S}$ & QM \\
\hline & $\mathrm{CC}$ & $\mathrm{D}$ \\
\hline \multirow{2}{*}{ Energy from fossil fuels/natural gas } & $\mathrm{S}$ & QM \\
\hline & $\mathrm{CC}$ & $\mathrm{D}$ \\
\hline \multirow{2}{*}{ Energy from fossil fuels/crude oil } & $\mathrm{S}$ & QM \\
\hline & $\mathrm{CC}$ & $\mathrm{D}$ \\
\hline
\end{tabular}

The conducted analysis of the survey results demonstrates very well the political, economic, environmental and social expectations related to the need of creating a portfolio of energy sources for the Eastern Poland macroregion by 2030. The performed analysis 
constitutes an important component of the energy portfolio, thus contributing to the implementation of certain elements of the New Green Deal in Poland.

\subsection{Potential Energy Portfolio of Eastern Poland Macroregion-Change of Forecast}

As a result of the conducted analyses of the conditions and premises for the transformation of the energy portfolio of the Eastern Poland macroregion, its change over time was projected. The scenario analysis enabled conclusions to be drawn. These indicate an upward trend in the development of renewable energy sources in particular for bioenergy, solar energy and wind energy with a positive impact on the development of the energy system and the highest probability of success (Table 6). Based on the responses given by the respondents, it can be assumed that the development and acquisition of energy from renewable sources occupies an important place in the energy policy directions adopted in the provinces (highest probability scenario). However, the result obtained from the worst-case scenario may be alarming, as it indicates the respondents' concern about the emergence of numerous threats limiting the development of RES in the macroregion of Eastern Poland. The obsolete distribution and transmission network in the Eastern Poland macroregion should be perceived as a threat in this respect [83].

Table 6. Energy portfolio development scenarios based on the renewable sources of the Eastern Poland macroregion in the perspective of 2030.

\begin{tabular}{|c|c|c|c|}
\hline Renewable Energy Sources & Trend & $\begin{array}{l}\text { Strength of Impact } \\
\text { from }-3 \text { to }+3\end{array}$ & $\begin{array}{c}\text { Probability } \\
0-1\end{array}$ \\
\hline \multirow{3}{*}{ Solar energy developmen } & growth & 1.5 & 0.6 \\
\hline & stabilisation & -1 & 0.3 \\
\hline & decrease & -2.5 & 0.1 \\
\hline \multirow{3}{*}{ Development of wind energy } & growth & 1 & 0.5 \\
\hline & stabilisation & -1 & 0.3 \\
\hline & decrease & -2 & 0.2 \\
\hline \multirow{3}{*}{ Development of hydrogen energy } & growth & -1 & 0.3 \\
\hline & stabilisation & -1.5 & 0.4 \\
\hline & decrease & -2 & 0.3 \\
\hline \multirow{3}{*}{$\begin{array}{l}\text { Development of energy from } \\
\text { cogeneration }\end{array}$} & growth & 1 & 0.4 \\
\hline & stabilisation & -1.5 & 0.4 \\
\hline & decrease & -2 & 0.2 \\
\hline \multirow{3}{*}{$\begin{array}{l}\text { Development of energy from } \\
\text { cogeneration }\end{array}$} & growth & 2 & 0.5 \\
\hline & stabilisation & -1 & 0.3 \\
\hline & decrease & -2 & 0.2 \\
\hline \multirow{3}{*}{$\begin{array}{l}\text { Development of energy from water } \\
\text { resources and geothermal energy }\end{array}$} & growth & -2 & 0.3 \\
\hline & stabilisation & -1.5 & 0.4 \\
\hline & decrease & -2 & 0.3 \\
\hline \multirow{3}{*}{$\begin{array}{l}\text { Development of energy from } \\
\text { decarbonised gases }\end{array}$} & growth & -1.5 & 0.5 \\
\hline & stabilisation & -1 & 0.3 \\
\hline & decrease & -2 & 0.2 \\
\hline Scenarios & \multicolumn{3}{|c|}{ Strength of Impact } \\
\hline optimistic (+) & \multicolumn{3}{|c|}{1.4} \\
\hline pessimistic (-) & \multicolumn{3}{|c|}{-2.1} \\
\hline the most probable $(+)$ & \multicolumn{3}{|c|}{1.5} \\
\hline the most probable $(-)$ & \multicolumn{3}{|c|}{-1.4} \\
\hline surprising (+) & \multicolumn{3}{|c|}{0} \\
\hline surprising (-) & \multicolumn{3}{|c|}{-1.9} \\
\hline
\end{tabular}


The results of the energy portfolio study in the Eastern Poland macroregion, based on the analysis of the collected data, differ from the conclusions resulting from the institutional and legal analysis. They indicate a high degree of portfolio diversification, which can take on an abnormal character: young for renewables and declining for non-renewables. The projected energy portfolio may become a weakness of the entire macroregion, which will impact the weakening development potential of Eastern Poland.

\section{Discussion}

The development of renewable energy in the Eastern Poland macroregion is very diverse. This is due to the structure of energy production in the country as a whole which differs fundamentally from the structure of obtaining energy from renewable sources for the EU-28 (Table 7) [84] (p. 20). Worryingly, however, the pessimistic macroeconomic conditions affecting the development of RES may hamper the dynamic development of the energy portfolio (transition of energy sources from the field of stars to the field of milk cows, or consolidation in the field of stars, or transition from the field of question marks to the field of stars.

Table 7. This is a specification of the contribution for renewable energy sources for Poland and the EU-28 (in percent).

\begin{tabular}{ccc}
\hline Specification for Year 2018 & Poland & EU-28 \\
\hline Solid biofuels & 68.1 & 40.3 \\
Solar energy & 0.9 & 6.4 \\
Hydro & 1.9 & 12.9 \\
Wind & 12.2 & 13.9 \\
Biogas & 3.2 & 7.1 \\
Liquid biofuels & 10.0 & 6.9 \\
Geothermal energy & 0.3 & 2.9 \\
Renewable municipal waste & 1.1 & 4.3 \\
Heat pumps & 2.4 & 5.4 \\
\hline
\end{tabular}

The predominance of energy obtained from biomass and biogas is a result of the essentially agricultural character of production in the Eastern Poland macroregion. It is also the least capital-intensive source of green energy in Poland. As this is a virtually self-contained process, the potential of this energy source in Poland, above all in the agricultural macroregion of Eastern Poland, as a basic energy resource can be underlined. It may be much more favourable from an ecological and economic point of view to the implementation of the objectives of the European Union's New Green Deal and the eventual transformation of the energy portfolio of the designated region. This creates the possibility of producing energy through cogeneration which is a more chemically fuel-efficient operation. The production of energy from decarbonised gases, particularly low-carbon (green) gases in the form of biomethane and hydrogen, should be noted here. Taking into account the development of prosumer economies, this way of generating energy can have a dual use in cogeneration, where the final product is both electricity and heat.

Solar energy can be an important component of Poland's energy portfolio, including its Eastern macroregion. Relative to 2018, in 2020, the energy supplier Energa Group connected more than 160 larger (above $50 \mathrm{~kW}$ ) RES sources to its network, of which there were 133 photovoltaic installations and 21 wind farms with a total installed capacity of over $330 \mathrm{MW}$ [85]. As a result, this segment can complement the energy derived from biofuels. This is dependent on the current level of technology and the climate, which determine the possibility of using solar energy in eastern Poland. The most efficient photovoltaic panels made of silicon currently available operate most efficiently at temperatures around $25{ }^{\circ} \mathrm{C}$. The lower the temperature, the fewer photons reach the cells, and the higher the temperature, the lower the power output of the panels. During the month of July, when the air temperature exceeds $30^{\circ} \mathrm{C}$ in Poland, there is a drop in efficiency and less electricity 
is produced. Moreover, when the panels are covered (by leaves, snow) the effects on the entire PV installation are similar [86].

The use of hydropower in the Eastern Poland macroregion creates the potential to transform the energy portfolio. The Warmińsko-Mazurskie and Podkarpackie provinces are the most promising for Polish hydropower. Eastern Poland's San and Bug rivers have the potential to generate $1013 \mathrm{GWh}$ per year [87]. However, this type of investment may be contested by the public as well as by local communities in the identified macroregion. The reason may be the development of natural waterways [88]. However, this does not apply to geothermal energy the production which in the case of the Eastern Poland macroregion is incidental in character.

Energy from wind turbines creates particular opportunities for the development of renewable energy in the macroregion of Eastern Poland. This is due to the geographical conditions that Eastern Poland has, i.e., extensive, windy terrain. However, this may be hindered by the bird habitats and rare plant areas protected by the European Union's Natura 2000 programme, which currently cover 19.7\% of Poland's area (Figure 11) [89]. These include 145 Special Protection Areas for birds covering 15.6\% of Poland's area and 845 Sites of Community Importance, which will be Special Habitat Areas following approval by the Minister of the Environment and cover 11.05\% of the country's area [90].

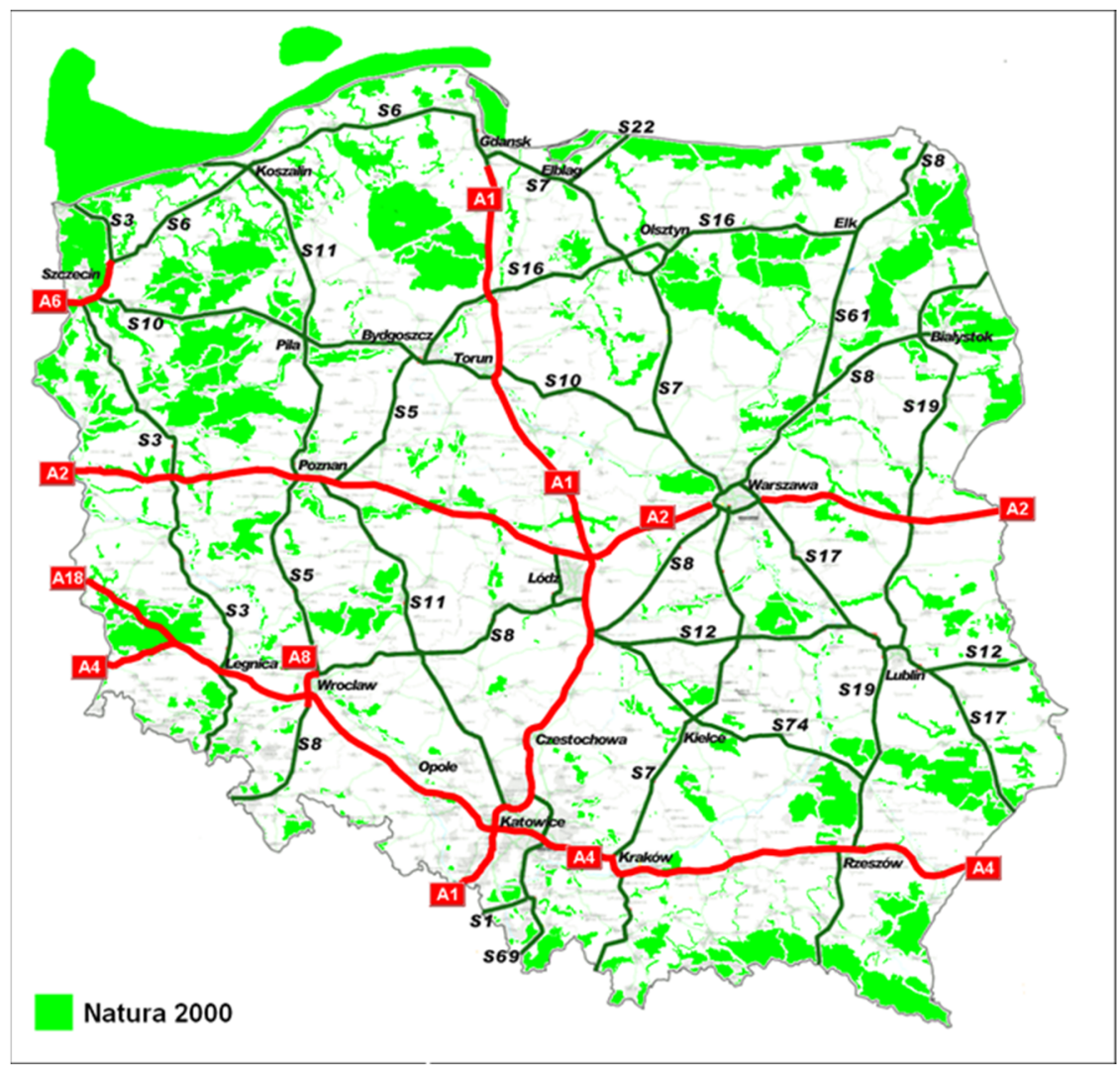

Figure 11. Natura 2000 protected areas in Poland.

The results of the study give rise to the conclusion that the selected energy sources will progress to the next phase of development. It is anticipated that the key energy source in the macroregion of Eastern Poland will be solar energy, and to a limited extent in certain areas-wind energy and bioenergy. Thus, creating an opportunity to implement the European Green Deal policy in this part of Europe (Table 8). 
Table 8. Forecast portfolio of energy sources for the Eastern Poland macroregion for 2030consolidated results.

\begin{tabular}{|c|c|c|}
\hline \multirow{2}{*}{ Energy Source } & \multicolumn{2}{|c|}{ Location in Energy Portfolio * } \\
\hline & \multicolumn{2}{|c|}{ In 2030} \\
\hline \multirow{2}{*}{ Solar energy } & $S$ & QM \\
\hline & $\mathrm{CC}$ & $\mathrm{D}$ \\
\hline \multirow{2}{*}{ Wind energy } & $\mathrm{S}$ & QM \\
\hline & $\mathrm{CC}$ & $\mathrm{D}$ \\
\hline \multirow{2}{*}{ Hydropower } & $\mathrm{S}$ & QM \\
\hline & $\mathrm{CC}$ & $\mathrm{D}$ \\
\hline \multirow{2}{*}{ Bioenergy } & S & QM \\
\hline & $\mathrm{CC}$ & $\mathrm{D}$ \\
\hline \multirow{2}{*}{ Energy from decarbonised gases } & $S$ & QM \\
\hline & $\mathrm{CC}$ & $\mathrm{D}$ \\
\hline \multirow{2}{*}{ Energy from cogeneration } & $S$ & QM \\
\hline & $\mathrm{CC}$ & $\mathrm{D}$ \\
\hline \multirow{2}{*}{ Energy from hydrogen } & $S$ & QM \\
\hline & $\mathrm{CC}$ & $\mathrm{D}$ \\
\hline \multirow{2}{*}{ Energy from fossil fuels/coal } & $\mathrm{S}$ & QM \\
\hline & $\mathrm{CC}$ & $\mathrm{D}$ \\
\hline \multirow{2}{*}{ Energy from fossil fuels/natural gas } & $\mathrm{S}$ & QM \\
\hline & $\mathrm{CC}$ & $\mathrm{D}$ \\
\hline \multirow{2}{*}{ Energy from fossil fuels/crude oil } & $S$ & QM \\
\hline & $\mathrm{CC}$ & $\mathrm{D}$ \\
\hline
\end{tabular}

* Legend: QM—experimental nascent phase/question marks; S—-key development phase/star/ stars; CC—key phase at maturity/cash cow; D—baseline dying phase/dog/dogs.

\section{Conclusions}

The development of the energy portfolio of the Eastern Poland macroregion is dependent on a number of factors which may be considered in the following perspectives: political, social, economic, technological and environmental. Together, they aim to protect the environment, ensure the continuity of entities, including entrepreneurs, cooperatives, farms and households. The existing energy portfolio of the Eastern Poland macroregion is unfavourable for the natural environment. How it will be altered over time using local renewable resources remains an open question. The adopted assumptions and goals set in the European Green Deal oblige Poland to changes which are intended to result in reaching EU climate neutrality by 2050, which is not without impact on the macroregion of Eastern Poland.

Poland, along with almost all other European Union countries, faces a major challenge, namely, the closure of fossil fuel power stations to eliminate their carbon footprint. The transitional raw material is to be the blue fuel, natural gas. Undoubtedly, given the projection of technological revolutions 4.0 and 5.0, and the successive increase in consumption, there will be an increase in energy production, including electricity from natural gas. In Poland, this increase is expected to be almost fivefold by 2030 (from 14 TWh to $54 \mathrm{TWh}$ ). This will mean the development of gas-fired power plants fuelled by natural gas or biomethane. This is an opportunity for the macroregion of Eastern Poland, which will balance its energy portfolio against the fossil fuels currently in use. The research has revealed the fledgling character of the energy portfolio of the Eastern Poland macroregion, with sustained growth 
in energy production from renewable sources over the past 10 years. It may result in their consolidation into the field of stars (mature stars) [85].

The results of the study of the energy portfolio of the Eastern Poland macroregion, based on the analysis of records in strategic documents and data collected in the course of the survey, indicate a high degree of diversification of the portfolio. It is currently of a youthful nature. The renewable energy sources in Eastern Poland can be categorised to varying degrees into the experimental area and the key area in the phase of source development. This provides a rationale for calling it a developing portfolio, with the proviso that its development will be determined by economic factors, including financial and legal drivers.

From the perspective of the completed survey and institutional and legal research, the forecasted energy portfolio for the Eastern Poland macroregion does not indicate the achievement of a balanced energy portfolio with the participation of RES. There is still a strong link between energy from fossil sources (Lubelskie province, coal, and Podkarpackie province, gas) and its generation based on existing infrastructure. In the short and medium term, this poses a risk to the achievement of the goals of the European Green Deal. The alternative is to develop distributed renewable energy, which requires the policy makers, with the support of local communities, to carry out in-depth analyses of the development of the local area, to increase social responsibility for the development of distributed renewable energy, as well as to provide comprehensive financial, organisational and legal solutions for the development of distributed renewable energy.

Based on analysis of the Eastern Poland macroregion, the final conclusions, which have the character of recommendations, are as follows. In order to achieve the policy goals of the European Green Deal, it is necessary to:

- Stimulate economic activity, competitiveness and innovation in the regional economy, shape spatial management and preserve the value of the cultural and natural environment;

- Increase commitment and investment in raising public awareness and competence in the regions in the area of distributed, prosumer energy;

- Develop detailed analyses, feasibility studies, programmes for individual regions/ provinces of the Eastern Poland macroregion scoping the anticipated energy transformation, taking into account the following issues: political/legal, economic/economic, social, geographical/environmental, and infrastructural/technological.

This will result in a faster and at the same time more efficient energy transition achieving climate neutrality by 2050, in accordance with the policies of the European Union's New Green Deal.

Author Contributions: Conceptualization, I.H., S.G., J.G., T.K., A.N.-K., M.P.-T., R.W.; Data curation, T.K., A.N.-K., R.W.; Formal analysis, T.K., A.N.-K., M.P.-T., R.W.; Investigation, I.H., S.G., J.G., A.N.K., M.P.-T., R.W.; Methodology, I.H., T.K., A.N.-K., M.P.-T., R.W.; Project administration, A.N.-K.; Resources, I.H., S.G., J.G.; Supervision, J.G., T.K., A.N.-K., R.W.; Validation, S.G., J.G.; Visualization, I.H., R.W.; Writing—original draft, T.K., A.N.-K., M.P.-T., R.W.; Writing—review and editing, I.H., S.G., J.G., T.K. All authors have read and agreed to the published version of the manuscript.

Funding: This research received no external funding.

Institutional Review Board Statement: Not applicable.

Informed Consent Statement: Not applicable.

Data Availability Statement: Not applicable.

Conflicts of Interest: The authors declare no conflict of interest. 


\section{References}

1. A Clean Planet for All a European Strategic Long-Term Vision for a Prosperous, Modern, Competitive and Climate Neutral Economy, Communication from the Commission to the European Parliament, the European Council, the Council, the European Economic and Social Committee, the Committee of the Regions and the European Investment Bank, Brussels. Available online: https:/ / eur-lex.europa.eu/legal-content/EN/TXT/PDF/?uri=CELEX:52018DC0773\&from=en (accessed on 1 July 2021).

2. Long-Term EU Budget 2021-2027 and Recovery Package, European Council. Available online: https:/ / www.consilium.europa. eu/en/policies/the-eu-budget/long-term-eu-budget-2021-2027/ (accessed on 1 January 2021).

3. Communication from the Commission to the European Parliament, the European Council, the Council, the European Economic and Social Committee and the Committee of the Regions. In The European Green Deal; European Commission: Brussels, Belgium. Available online: https: / / eur-lex.europa.eu/legal-content/PL/TXT/DOC/?uri=CELEX:52019DC0640\&from=EN (accessed on 1 January 2021).

4. Zhelyazkova, A.; Bølstad, J.; Meijers, M.J. Understanding responsiveness in European Union politics: Introducing the debate. J. Eur. Public Policy 2019, 26, 1715-1723. [CrossRef]

5. Turnhout, E.; Behagel, J.; Ferranti, F.; Beunen, R. The construction of legitimacy in European nature policy: Expertise and participation in the service of cost-effectiveness. Environ. Politics 2015, 24, 461-480. [CrossRef]

6. Steen, M.; Faller, F.; Ullern, E.F. Fostering renewable energy with smart specialisation? Insights into European innovation policy. Nor. J. Geogr. 2019, 73, 39-52. [CrossRef]

7. Jänicke, M.; Wurzel, R.K.W. Leadership and lesson-drawing in the European Union's multilevel climate governance system. Environ. Politics 2019, 28, 22-42. [CrossRef]

8. Eckert, E.; Kovalevska, O. Sustainability in the European Union: Analyzing the Discourse of the European Green Deal. J. Risk Financ. Manag. 2021, 14, 80. [CrossRef]

9. Johnston, A.; Regan, A. Introduction: Is the European Union Capable of Integrating Diverse Models of Capitalism? New Political Econ. 2018, 23, 145-159. [CrossRef]

10. Gawlik, L. Energy transition in Poland. In Energy Policy Transition-The Perspective of Different States; Ruszel, M., Młynarski, T., Szurlej, A., Eds.; Ignacy Lukasiewicz Energy Policy Institute: Rzeszów, Poland, 2017; pp. 171-182.

11. Gryz, J.; Kaczmarczyk, B. Toward Low-Carbon European Union Society: Young Poles' Perception of Climate Neutrality. Energies 2021, 14, 5107. [CrossRef]

12. Braun, J. State aid for environmental protection and energy objectives in Poland and other countries of the European Union. Optimum. Econ. Stud. 2020, 102, 69-78. [CrossRef]

13. Melnikas, B. Creation of knowledge—based economy in the European Union: The main typicalities and new ideas of clusterization. J. Bus. Econ. Manag. 2005, 6, 87-100. [CrossRef]

14. Geden, O.; Peters, G.P.; Scott, V. Targeting carbon dioxide removal in the European Union. Clim. Policy 2019, 19, 487-494. [CrossRef]

15. “European Green Deal"—New European Development Vision. Available online: https://raport.togetair.eu/human/people-theworld-the-climate/european-green-deal-new-european-development-vision (accessed on 1 May 2021).

16. Lachapelle, E.; MacNeil, R.; Paterson, M. The political economy of decarbonisation: From green energy 'race' to green 'division of labour'. New Political Econ. 2017, 22, 311-327. [CrossRef]

17. Ruszel, M.; Młynarski, T.; Szurlej, A. The concept of energy transition. In Energy Policy Transition-The Perspective of Different States; Ruszel, M., Młynarski, T., Szurlej, A., Eds.; Ignacy Lukasiewicz Energy Policy Institute: Rzeszów, Poland, 2017; pp. 28-37.

18. Eastern Poland Programme, Programme Objectives. Available online: https://www.polskawschodnia.gov.pl/strony/oprogramie/fe-dla-polski-wschodniej-2021-2027 / zalozenia-nowego-programu (accessed on 1 January 2021).

19. Energy from Renewable Sources in 2019; Central Statistical Office: Warsaw, Poland, 2020; pp. 13-19. Available online: https: / / stat.gov.pl/en/topics/environment-energy/energy/energy-from-renewable-sources-in-2019,3,12.html?pdf=1 (accessed on 1 May 2021).

20. Renewable Energy Sources, Green Zones. Available online: https://zielonestrefy.pl/zielone-strefy/odnawialne-zrodla-energii/ (accessed on 1 June 2021).

21. Program Operacyjny Polska Wschodnia 2014-2020 (Operational Programme Eastern Poland 2014-2020) (POPW). Available online: https://www.polskawschodnia.gov.pl/media/94092/POPW_8092020.pdf (accessed on 20 September 2021).

22. Available online: swaid.stat.gov.pl/AtlasRegionow / AtlasRegionowMapa.aspx (accessed on 8 May 2021).

23. Polska Wschodnia: Biała plama Energetyczna czy Nie?-Energetyka. Available online: https://www.wnp.pl/energetyka/ polska-wschodnia-biala-plama-energetyczna-czy-nie,234296.html (accessed on 1 January 2021).

24. Operational Programme Eastern Poland about the Programme. Available online: https://www.polskawschodnia.gov.pl/strony/ o-programie/zasady/fe-2007-2013 (accessed on 1 January 2021).

25. Siemiatkowski, P.; Tomaszewski, P.; Marszałek-Kawa, J.; Gierszewski, J. The Financing of Renewable Energy Sources and the Level of Sustainable Development of Poland's Provinces in the Area of Environmental Order. Energies 2020, 13, 5591. [CrossRef]

26. Zhou, W.; Zhu, W.; Chen, Y.; Chen, J. Dynamic changes and multi-dimensional evolution of portfolio optimization. Econ. Res. 2021, 34, 1-26. [CrossRef]

27. Dohleman, B.S. Exploratory social network analysis with Pajek. Psychometrika 2006, 71, 605-606. [CrossRef] 
28. Hanif, W.; Hernandez, J.A.; Shahzad, J.; Hoang, T.H.-V.; Yoon, S.-M. Regional and copula estimation effects on EU and US energy equity portfolios. Appl. Econ. 2020, 52, 5311-5342. [CrossRef]

29. Ahmad, W.; Rais, S. Time-Varying Spillover and the Portfolio Diversification Implications of Clean Energy Equity with Commodities and Financial Assets. Emerg. Mark. Financ. Trade 2018, 54, 1837-1855. [CrossRef]

30. Owusu, P.A.; Asumadu-Sarkodie, S. A review of renewable energy sources, sustainability issues and climate change mitigation. Cogent Eng. 2016, 3, 1167990. [CrossRef]

31. Fang, M.; Tan, K.S.; Wirjanto, T.S. Sustainable portfolio management under climate change. J. Sustain. Financ. Investig. 2019, 9 , 45-67. [CrossRef]

32. Brown, E.; Campbell, B.; Cloke, J.; To, L.S.; Turner, B.; Wray, A. Low carbon energy and international development: From research impact to policymaking. Contemp. Soc. Sci. 2018, 13, 112-127. [CrossRef]

33. Bourgeois, L.J.; Duhaime, I.M.; Stimpert, J.L. Strategic Management Concise: A managerial Perspective; Horcourt College Publishers: Fort Worth, TX, USA, 2001; p. 238.

34. Lynch, R. Corporate Strategy; Prentice Hall: Harlow, UK, 2000; pp. 176-177.

35. Segev, E. Business Unit Strategy; John Wiley \& Sons: Chichester, UK, 2000; pp. 155-156.

36. Henderson, B. The Product Portfolio, The Boston Consulting Group. 1 January 1970. Available online: https:/ www.bcg.com/ publications /1970/strategy-the-product-portfolio (accessed on 1 May 2021).

37. Mascaraenhas, B.; Aaker, D.A. Strategy over the Business Cycle. Strateg. Manag. J. 1989, 10, 199-210. [CrossRef]

38. Chatterjee, S. From Cycles to Shocks: Progress in Business Cycle Theory. Business Review 3, March/April 2000. pp. 1-10. Available online: https:/ / fraser.stlouisfed.org/title/business-review-federal-reserve-bank-philadelphia-5580/march-april-20 00-557711/cycles-shocks-522287 (accessed on 1 January 2021).

39. Bayus, B. An Analysis of Product Lifetimes in a Technologically Dynamic Industry. Manag. Sci. 1998, 44, 763-775. [CrossRef]

40. Power and Utilities. Available online: https://www.bcg.com/industries/energy/power-utilities/overview (accessed on 21 November 2021).

41. Benchmark Your Building Using ENERGY STAR®Portfolio Manager®, Benchmark Your Building Using ENERGY STAR ${ }$ Portfolio Manager ${ }^{\circledR}$. Available online: www.energystar.gov/buildings/benchmark (accessed on 1 October 2021).

42. Pyka, I.; Nocon, A. Responsible Lending Policy of Green Investments in the Energy Sector in Poland. Energies 2021, 14, 7298. [CrossRef]

43. Ahmed, M.M.; Shimada, K. The Effect of Renewable Energy Consumption on Sustainable Economic Development: Evidence from Emerging and Developing Economies. Energies 2019, 12, 2954. [CrossRef]

44. Brodny, J.; Tutak, M.; Saki, S.A. Forecasting the Structure of Energy Production from Renewable Energy Sources and Biofuels in Poland. Energies 2020, 13, 2539. [CrossRef]

45. Johnson, G.; Scholes, K. Exploring Corporate Strategy; Prentice Hall Europe: London, UK, 1999; p. 104.

46. Bowman, C. Strategy in Pracice; Prentice Hall: Harlow, UK, 1998; pp. 89-90.

47. Bradfield, R.; Wright, G.; Burt, G.; Cairmst, G.; van der Heijden, K. The origins and evolution of scenario techniques in long range business planning. Futures 2005, 37, 795-812. [CrossRef]

48. Tapera, J. The Importance of Strategic Management to Business Organizations. Int. J. Res. J. Soc. Sci. Manag. 2014, 3, 126. Available online: https://www.researchgate.net/publication/301801352_The_Importance_of_Strategic_Management_to_ Business_Organizations (accessed on 16 May 2021).

49. Walden, J. Comparison of the STEEPLE Strategy Methodology and the Department of Defense's PMESII-PT Methodology; Supply Chain Leadership Institute. 2011. Available online: http://www.supplychainresearch.com/images/Walden_Strategy_Paper.pdf (accessed on 10 May 2021).

50. Knoniuk, A. Analiza STEEPVL na przykładzie projektu Foresight technologiczny. "NT FOR Podlaskie 2020" regionalna strategia rozwoju nanotechnologii. Econ. Manag. 2010, 4, 110.

51. Pickton, D.; Broderick, A. Integrated Marketing Communications; Pearson Education: Harlow, UK, 2001; p. 120.

52. Energis (A) PESTEL/PEST/STEP Analysis \& Solution/MBA Resources, MBA PESTEL: Energis (A) Pestel/Analiza. Available online: https:/ / embapro.com/frontpage/pestelcase/15889-energis-altnets (accessed on 1 January 2021).

53. Narayanan, V.; Fahey, L. Macroenvironmental Analysis: Understanding the Environment Outside the Industry. In The Portable MBA in Strategy; Fahey, L., Randall, R., Eds.; John Wiley \& Sons: New York, NY, USA, 2001; pp. 189-200.

54. Portfel Energetyczny Wybranych Regionów Unii Europejskiej. Available online: https://forms.office.com/r/ty3gN7rLtJ (accessed on 1 January 2021).

55. Europejski Zielony Ład, COM(2019) 640 Final, Komisja Europejska, Bruksela, Belgia. 2019. Available online: https: / /ec.europa. eu/transparency / documents-register/detail? ref=COM(2019)640 (accessed on 4 May 2021).

56. Wettengel, J. Covering the EU's "Fit for 55" Package of Climate and Energy Laws, Journalism for the Energy Transtion, 14 July 2021, Covering the EU's “Fit for 55" Package of Climate and Energy Laws I Clean Energy Wire. Available online: https:/ / www.edf.org/media / fit-55-turns-eus-climate-target-action-challenging-other-major-economies-follow (accessed on 21 August 2021).

57. Polska w Zielonym Ładzie,_Korzyści, Możliwości i Ocena SWOT, Opinie i Ekspertyzy OE-307. Available online: https: //www.senat.gov.pl/gfx/senat/pl/senatekspertyzy/5619/plik/oe_307.pdf (accessed on 21 August 2021). 
58. Krajowy Plan Odbudowy i Zwiększania Odporności; Ministerstwo Funduszy i Polityki Regionalnej: Warszawa. 2021. Available online: https: / / www.gov.pl/web/planodbudowy/czym-jest-kpo2 (accessed on 4 May 2021).

59. Notice of the Minister of Climate and Environment of 2 March 2021; Polish Official Gazette: Warsaw, Poland, 2021.

60. Warmińsko-Mazurskie 2030. Strategia Rozwoju Społeczno-Gospodarczego; Olsztyn. 2020. Available online: https://strategia. warmia.mazury.pl/strategia-2030/ (accessed on 15 May 2021).

61. Strategia Rozwoju Społeczno-Gospodarczego Województwa Warmińsko-Mazurskiego do Roku 2020; Zarząd Województwa: Olsztyn, Poland, 2005. Available online: https:/ / strategia.warmia.mazury.pl/poprzednie-strategie/ (accessed on 15 May 2021).

62. Kontrakt Terytorialny dla Województwa Warmińsko-Mazurskiego; Zarząd Województwa Warmińsko-mazurskiego: Olsztyn, Poland. 2014. Available online: https://docplayer.pl/112540422-Kontrakt-terytorialny-dla-wojewodztwa-warminskomazurskiego.html (accessed on 1 June 2021).

63. Strategia Rozwoju Województwa Podlaskiego do Roku 2020; Urząd Marszałkowski Województwa Podlaskiego. 2013. Available online: https:/ / strategia.wrotapodlasia.pl/pl/ps2/var/resources/154/248/4/srwp_2020_1.pdf (accessed on 1 June 2021).

64. Strategia Rozwoju Województwa Podlaskiego 2030; Departament Rozwoju Regionalnego UMWP: Białystok, Poland. 2020. Available online: https:/ / strategia.wrotapodlasia.pl/pl/strategia_rozwoju_wojewdztwa_podlaskiego_2030/ (accessed on 1 June 2021).

65. Kontrakt Terytorialny dla Województwa Podlaskiego; Serwis Regionalnego Programu Województwa Podlaskiego. 2014. Available online: https:/ / rpo.wrotapodlasia.pl/pl/dowiedz_sie_wiecej_o_programie/zapoznaj_sie_z_prawem_i_dokument/kontraktterytorialny-dla-wojewodztwa-podlaskiego.html (accessed on 1 June 2021).

66. Lubelskie Province Development Strategy 2014-2020; Lubelskie Provincial Marshal's Administration: Lublin, Poland, 2014. Available online: https://lublin.eu/gfx/lublin/userfiles/_public/pliki_do_pobrania/strategia_rozwoju_lublina_na_lat/lublin_ development_strategy_2013-2020.pdf (accessed on 1 June 2021).

67. Strategia Rozwoju Województwa Lubelskiego do 2030 Roku; Zarząd Województwa Lubelskiego: Lublin, Poland, 2021. Available online: https: / strategia.lubelskie.pl/srwl/srwl.2021.04.02.pdf (accessed on 29 May 2021).

68. Kusińska, E. Contemporary Cities of the Ruhr-Green Post-Industrial Agglomerations. Hous. Environ. 2018, $24,179-185$. Available online: https:/ / repozytorium.biblos.pk.edu.pl/resources/41455 (accessed on 1 June 2021).

69. Regionalna Strategia Innowacji Województwa Lubelskiego do 2020 Roku; Lublin, Poland. 2014. Available online: https: / www. researchgate.net/publication/308379380_Regionalna_Strategia_Innowacji_Wojewodztwa_Lubelskiego_do_roku_2020 (accessed on 1 June 2021).

70. Strategia Rozwoju Województwa Świętokrzyskiego do 2020 Roku; Uchwała Nr XXXIII/589/13 Sejmiku Województwa Świętokrzyskiego z Dnia 16 Lipca 2013 r. Available online: https://www.swietokrzyskie.pro/file/2019/07/Strategia-RozwojuWojew\%C3\%B3dztwa-\%C5\%9Awi\%C4\%99tokrzyskiego-do-roku-2020.pdf (accessed on 1 June 2021).

71. Kwaśniewski, D. Efektywność energetyczna produkcji biomasy z trzyletniej wierzby. Inżynieria Rol. 2010, 5, 113-119.

72. Świętokrzyskie Centrum Innowacji i Transferu Technologii. Available online: https://it.kielce.pl/ (accessed on 29 May 2021).

73. Strategia Rozwoju Województwa Świętokrzyskiego 2030+; Załącznik do Uchwały nr XXX/406/21 Sejmiku Województwa Świętokrzyskiego, z Dnia 29 Marca 2021, Kielce. 2021. Available online: https:/ / www.swietokrzyskie.pro/ category/wojewodztwoswietokrzyskie/strategia-rozwoju-wojewodztwa-swietokrzyskiego-2030 (accessed on 29 May 2021).

74. Pacocha, A.K. Perspektywy Rozwoju Odnawialnych Źródeł Energii w Świętokrzyskiem; Departament Rozwoju Obszarów Wiejskich Urzędu Marszałkowskiego. 2012. Available online: https: / / www.swietokrzyskie.pro/perspektywy-rozwoju-odnawialnychzrodel-energii-w-swietokrzyskiem/ (accessed on 10 May 2021).

75. Uszczegółowienie Inteligentnych Specjalizacji Województwa Świętokrzyskiego. Załącznik 1. do Planu Wykonawczego do RIS3. 2015. Available online: http:/ / www.2014-2020.rpo-swietokrzyskie.pl/dowiedz-sie-wiecej-o-programie/zapoznaj-sie-z-prawemi-dokumentami/dokumenty-regionalne/item/210-regionalne-inteligentne-specjalizacje-wojewodztwa-swietokrzyskiego (accessed on 30 May 2021).

76. Strategia Rozwoju Województwa-Podkarpackie 2030; Rzeszów, Poland. 2020. Available online: https:/ / www.podkarpackie. $\mathrm{pl}$ /index.php/strategia/7812-strategia-rozwoju-wojewodztwa-podkarpackie-2030-przyjeta-przez-sejmik-wojewodztwapodkarpackiego (accessed on 30 May 2021).

77. Kwinta, W. Więcej Gazu Ziemnego w Starym Złożu. 2020. Available online: https://inzynieria.com/paliwa/wiadomosci/59167, podkarpacie-odkryto-nowe-zloze-gazu-ziemnego (accessed on 29 May 2021).

78. Wojewódzki Program Rozwoju Odnawialnych Źródeł Energii dla Województwa Podkarpackiego. 2013. Available online: https:/ / bip.podkarpackie.pl/attachments/article/1020/874_1.pdf (accessed on 15 June 2021).

79. Projekt Polskiej Strategii Wodorowej do 2030 r. Available online: http:/ / www.airproducts.com.pl/ (accessed on 12 June 2021).

80. Biznes. Inteligentne Specjalizacje Województwa Podkarpackiego. Available online: https://podkarpackie.eu/biznes/ inteligentne-specjalizacje-wojewodztwa-podkarpackiego/ (accessed on 15 June 2021).

81. Kontrakt Terytorialny dla Wojezództwa Podkarpackiego; Zarząd Województwa Podkarpackiego: Rzeszów, Poland, 2014. Available online: https:/ / www.podkarpackie.pl/index.php/rozwoj-regionalny/kontrakt-terytorialny/5194-kontrakt-terytorialnypodstawowe-dokumenty (accessed on 10 June 2021).

82. Na Podkarpaciu Będzie Produkowany Zielony Wodór. Powstanie Dolina Wodorowa. GLOBEnergia. Available online: https: //globenergia.pl/podkarpacka-dolina-wodorowa-zielony-wodor-oze-energetyka/ (accessed on 19 May 2021). 
83. Krajowa Strategia Rozwoju Regionalnego 2030. Rozwój Społecznie Wrażliwy i Terytorialnie Zrównoważony; Warszawa, Poland. 2019, p. 27. Available online: http://ekonomiaspoleczna.lubelskie.pl/images/artykuly/2019/strategia_rozwoju/krajowa_ strategia_rozwoju_regionalnego_2030.pdf (accessed on 10 June 2021).

84. Energia ze Źródeł Odnawialnych w 2019 r; Główny Urząd Statystyczny: Warszawa, Poland, 2020. Available online: https: / stat.gov. $\mathrm{pl} /$ obszary-tematyczne/srodowisko-energia/energia/energia-ze-zrodel-odnawialnych-w-2019-roku,10,3.html (accessed on 25 September 2021).

85. Europe's Energy Transition, Renewables Overtook Fossil Fuels in European Energy Generation Last Year for the First Time. Geopolitical Futures, 29 January 2021, Europe's Energy Transition I Geopolitical Futures, 29 January 2021. Available online: https:/ / geopoliticalfutures.com/europes-energy-transition/ (accessed on 21 August 2021).

86. Oozeki, T.; Izawa, T.; Otani, K.; Kurokawa, K. An evaluation method of PV systems. Sol. Energy Mater. Sol. Cells 2003, 75, 687-695. [CrossRef]

87. Fodrowska, K. Elektrownie Wodne w Polsce (Hydroelectric Power Plants in Poland), Enerad.pl. Available online: https: / / enerad.pl/aktualnosci/elektrownie-wodne-w-polsce/ (accessed on 22 August 2021).

88. Hydroelektrownie Szkodzą Środowisku i Naszym Finansom (Hydroelectric Power Plants Harm the Environment and Our Finances). WWF Polska. Available online: https://www.wwf.pl/aktualnosci/hydroelektrownie-szkodza-srodowisku-i-naszymfinansom (accessed on 22 August 2021).

89. Drogi a Środowisko, Stowarzyszenie Integracji Stołecznej Komunikacji. Available online: http://www.siskom.waw.pl/nauka/ srodowisko/natura2000-sip-konflikty.PNG/ (accessed on 20 August 2021).

90. Regional Directorate of State Forests in Zielona Góra. Available online: https:/ /www.zielonagora.lasy.gov.pl/obszary-natura-20 00\#.YSOIg44zaUk (accessed on 23 August 2021). 